\title{
Review Article \\ The Calcium-Dependent Interaction of S100B with Its Protein Targets
}

\author{
Danna B. Zimmer' ${ }^{1}$ and David J. Weber ${ }^{2}$ \\ ${ }^{1}$ Department of Veterinary Pathobiology, College of Veterinary Medicine, Texas A \& M University, MS 4467 College Station, \\ TX 77843-4467, USA \\ ${ }^{2}$ Department of Biochemistry \& Molecular Biology, University of Maryland School of Medicine, \\ 108 N. Greene St. Baltimore, MD 21204, USA
}

Correspondence should be addressed to David J. Weber, dweber@som.umaryland.edu

Received 20 April 2010; Accepted 9 June 2010

Academic Editor: Claus W. Heizmann

Copyright ( 2010 D. B. Zimmer and D. J. Weber. This is an open access article distributed under the Creative Commons Attribution License, which permits unrestricted use, distribution, and reproduction in any medium, provided the original work is properly cited.

S100B is a calcium signaling protein that is a member of the S100 protein family. An important feature of S100B and most other S100 proteins (S100s) is that they often bind $\mathrm{Ca}^{2+}$ ions relatively weakly in the absence of a protein target; upon binding their target proteins, $\mathrm{Ca}^{2+}$-binding then increases by as much as from 200 - to 400 -fold. This manuscript reviews the structural basis and physiological significance of increased $\mathrm{Ca}^{2+}$-binding affinity in the presence of protein targets. New information regarding redundancy among family members and the structural domains that mediate the interaction of S100B, and other S100s, with their targets is also presented. It is the diversity among individual S100s, the protein targets that they interact with, and the Ca ${ }^{2+}$ dependency of these protein-protein interactions that allow S100s to transduce changes in $\left[\mathrm{Ca}^{2+}\right]_{\text {intracellular }}$ levels into spatially and temporally unique biological responses.

\section{Introduction}

$\mathrm{Ca}^{2+}$ ions are important second messengers in all living cells [1]. $\mathrm{Ca}^{2+}$-binding proteins, including members of the calmodulin/troponin/S100 superfamily, maintain the integrity of the $\mathrm{Ca}^{2+}$ signal and transmit it in a temporally and spatially coordinated manner [2]. S100s were discovered in 1965 [3], and as with other EF-hand containing proteins, S100s also transduce changes in $\left[\mathrm{Ca}^{2+}\right]_{\text {intracellular levels (i.e., }}$ $\left[\mathrm{Ca}^{2+}\right]_{\mathrm{i}}$ ) into cellular responses by binding $\mathrm{Ca}^{2+}$ (Table 1 ), changing conformation, and then interacting with and modulating the activity of other proteins (target proteins) (Figure 1). The amino acid homology between the current family members ranges from approximately $20 \%$ to $55 \%$ [4]. Because of the extensive amino acid homology between S100B and S100A1, the first two family members identified, early models predicted that individual members were functionally redundant and essentially interchangeable. As the number of family members discovered has increased and differences in their cellular/subcellular localization, physical properties, and target proteins have expanded, additional models have arisen with specific S100 family members having unique biological functions [5-12]. This multigenic family now contains up to twenty-one members (humans) whose phylogenetic distribution is restricted to higher chordates. Oligomerization properties, affinities for divalent metal ions $\left(\mathrm{Ca}^{2+}, \mathrm{Zn}^{2+}, \mathrm{Cu}^{2+}\right)$, and posttranslational modifications also contribute to diversity among S100 family members [7, 12]. Furthermore, each cell/tissue expresses a unique subset of family members $[11,12]$. Collectively, these findings support the view that S100s often confer cell type specificity to $\mathrm{Ca}^{2+}$ signal transduction pathways in cells and tissues [11-16].

The 3-dimensional structure of numerous S100 proteins has been solved by NMR and X-ray crystallography techniques in the apo-, $\mathrm{Ca}^{2+}$-bound, $\mathrm{Zn}^{2+}$-bound, drug-bound, and target protein bound states, and with the exception of calbindin $\mathrm{D}_{9 \mathrm{~K}}, \mathrm{~S} 100$ s such as $\mathrm{S} 100 \mathrm{~B}$ are typically symmetric dimers with each subunit containing two EF-hand calciumbinding domains, although, some higher-order oligomeric 


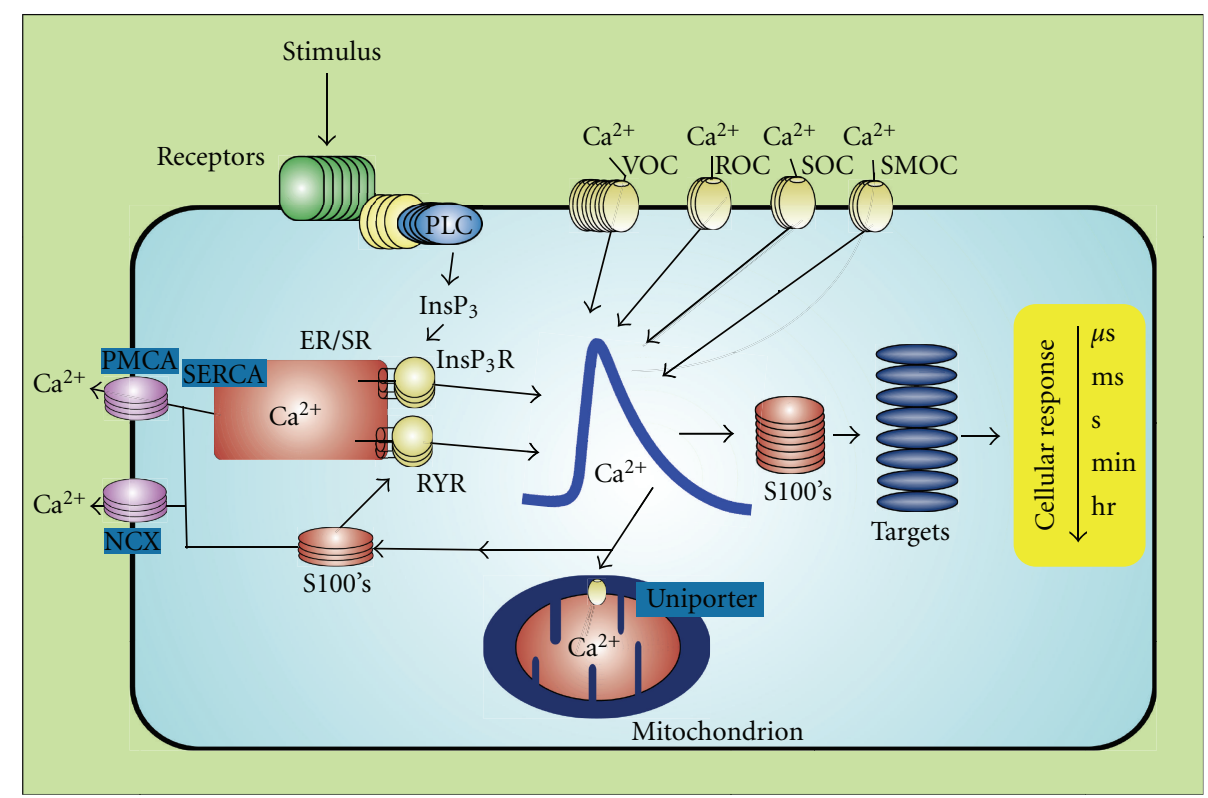

FIGURE 1: S100s function as $\mathrm{Ca}^{2+}$-signaling proteins. S100s bind and regulate protein targets as well as other $\mathrm{Ca}^{2+}$-signaling proteins in a $\mathrm{Ca}^{2+}$-dependent manner. S100s are distributed in a cell-specific manner to generate cell-type specific activities $[1,2,10]$.

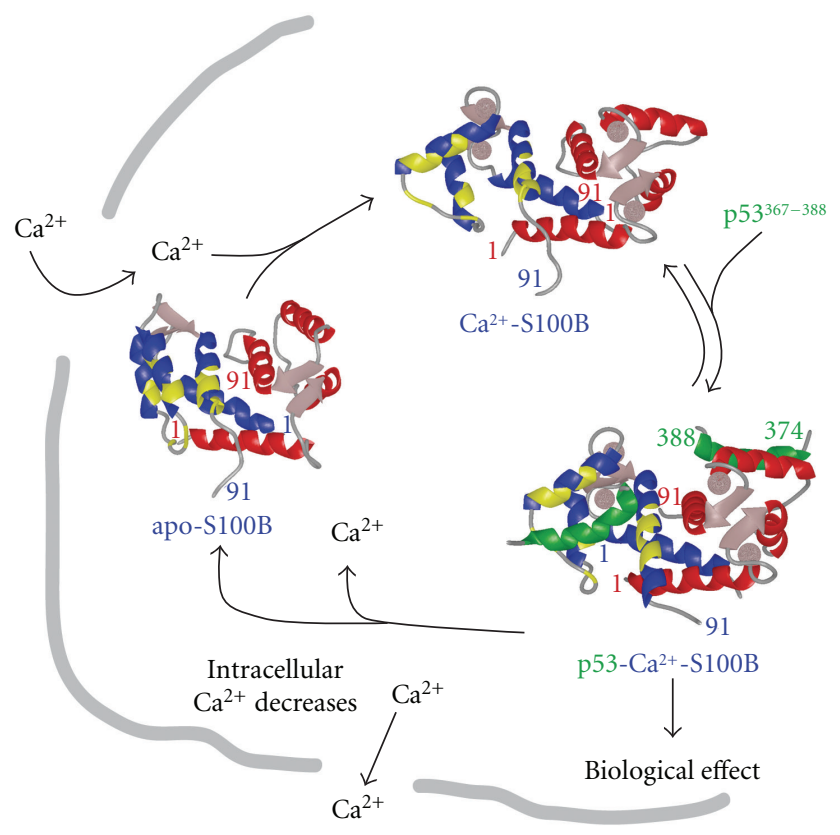

FIGURE 2: The $\mathrm{Ca}^{2+}$-dependent S100-target protein interactions. In $\mathrm{red} / \mathrm{blue}$ are subunits of S100B $\left({ }^{\text {dimer }} \mathrm{K}_{\mathrm{D}}<500 \mathrm{pM}[1,17]\right)$ with regions shaded (yellow) for residues that bind targets such as p53 $367-388$ (green), p53 (p53 $\left.321-346, K_{D}=24 \pm 10 \mathrm{nM}\right)$, or TRTK12 $[10,18]$.

states have also been detected and discussed [17-64]. The first EF-hand motif (EF1) in each subunit has fourteen rather than twelve residues and is termed the "pseudo-EFhand" or "S100 EF-hand" [31, 65]. Another unique feature of the S100-hand (EF1) is that calcium-coordination is achieved via backbone carbonyl oxygen atoms rather than sidechain carboxylate oxygen atoms, and it typically binds $\mathrm{Ca}^{2+}$ rather weakly $\left(\mathrm{K}_{\mathrm{D}}>0.5 \mathrm{mM}\right)$. The second EF-hand (EF2) is termed the "typical EF-hand" since it has the same number of residues as most EF-hand $\mathrm{Ca}^{2+}$-binding proteins (i.e., twelve), and it exactly matches the consensus EF-hand in both sequence and three-dimensional structure [66]. As with the helix-loop-helix $\mathrm{Ca}^{2+}$ binding domains of other members of the EF-hand superfamily (i.e., calmodulin, troponin $\mathrm{C}$, etc.), the second EF-hand of S100B coordinates $\mathrm{Ca}^{2+}$ via a backbone carbonyl oxygen at position 7 , sidechain oxygen atoms from Asp/Glu at positions 1, 3, and 5, and via bidentate coordination from oxygen atoms from a Glu sidechain at position 12 [66]. Position 9 of the coordination scheme is occupied by a water molecule that is, in turn, hydrogen-bonded to a Glu sidechain oxygen atom from the pseudo-EF-hand. Another feature of S100B and several other S100s is that several of them bind $\mathrm{Ca}^{2+}$ ions relatively weakly, relative to $\left[\mathrm{Ca}^{2+}\right]_{\mathrm{i}}$, in the absence of a protein target $\left(\mathrm{K}_{\mathrm{D}} \geq 1 \mu \mathrm{M}\right)$. However, upon binding their full-length target protein, $\mathrm{Ca}^{2+}$-binding can then increase by as much as from 200- to 400-fold [60,67]. This feature could allow for cells to contain high concentrations of some S100s, such as $\mathrm{S} 100 \mathrm{~B}(>1 \mu \mathrm{M})$, without depleting $\left[\mathrm{Ca}^{2+}\right]_{\mathrm{i}}$ levels and "shortcircuiting" $\mathrm{Ca}^{2+}$ oscillations necessary for signaling.

The large number of protein targets that S100B and other S100 family members bind and regulate provides yet another level of diversity/complexity to S100 signaling. Examination of the extensive lists of S100 target proteins provides important insights regarding $S 100$ signaling $[15,68$, 69]. First, S100s regulate a wide-range of cellular processes that includes energy metabolism, cytoskeleton organization, gene expression, and signal transduction pathways. Second, the list of in vitro target proteins for individual family members can be extensive, 23-25 different protein 
targets have been reported for S100B and S100A1 alone $[5,7,13,15,68,70]$. Third, some target proteins interact with and have their activity modulated by multiple $\$ 100$ family members suggesting functional redundancy among some family members. For example, both S100A1 and S100B interact with and activate aldolase $\mathrm{A}$ and aldolase C [71]. In contrast, S100A1 and S100B exhibit a $\mathrm{Ca}^{2+}$ dependent interaction with phosphoglucomtutase but this interaction results in differential effects on target protein activity: S100A1 stimulates phosphoglucomutase activity and S100B inhibits phosphoglucomutase activity [72]. Like phosphoglucomutase, both S100A1 and S100B bind glycogen phosphorylase a [73]. However, S100A1 inhibits and S100B has no effect on glycogen phosphorylase activity. Interestingly, S100A4, S100A1, and S100A6 interact with methionine aminopeptidase 2, but with different affinities [74]. The S100A6 (calcyclin) binding protein CACYBP also interacts with S100A1, S100A12, S100P, and S100B but not S100A4 [75]. And several S100 proteins (i.e., S100A1, S100A2, S100A4, S100A6, and S100B) bind to p53, p63, p73 $[29,76-80]$, and affect their biological functions [8184]. Fifth, S100 activation of some target proteins is $\mathrm{Ca}^{2+}$ independent indicating that $S 100$ s sense changes in $\left[\mathrm{Ca}^{2+}\right]_{i}$ levels and have important intracellular functions at both resting and stimulated $\left[\mathrm{Ca}^{2+}\right]_{\mathrm{i}}$ levels. Sixth, a subset of S100s have a conserved $\mathrm{Zn}^{2+}$-binding site that contributes to altered $\mathrm{Ca}^{2+}-$, target-, and in some cases, small molecule binding affinity in vitro $[8,20,36,40,68,85-99]$, which could potentially affect cellular functions. Seventh, the interaction of S100 family members with other family members as "target proteins" has been observed using yeast-two hybrid approaches [100-104]. Finally, S100 proteins may exert some of their effects via interaction with molecules other than proteins. For example, S100A8/S100A9 binds (poly) unsaturated fatty acids in a $\mathrm{Ca}^{2+}$-dependent manner [105, 106] and S100A1 binds $\mathrm{IP}_{3}$ (Baron, Coburn, and Zimmer, personal communication). New information regarding S100 family member specificity for individual target proteins and the structural motifs that mediate these interactions are detailed below. As discussed, the diversity among individual S100s, the protein targets that they interact with, and the $\mathrm{Ca}^{2+}$ dependency of these interactions are uniquely suited to conferring cell-type specificity to $\mathrm{Ca}^{2+}$-signaling pathways.

1.1. The S100 Calcium-Switch. Biophysical and structural biology techniques are used to study molecular determinants involved in $\mathrm{Ca}^{2+}$-dependent S100-target interactions. A comparison of apo- and $\mathrm{Ca}^{2+}$-bound S100B $\left(\mathrm{B}^{2} \mathrm{Ca}^{2+}\right)$ indicates that the pseudo -EF-hand $\left(\mathrm{EF} 1,{ }^{\mathrm{Ca}} \mathrm{K}_{\mathrm{D}}>350 \mu \mathrm{M}\right.$, Table 1) has minor structural changes when $\mathrm{Ca}^{2+}$ binds, whereas, the typical EF-hand $\left(\mathrm{EF} 2{ }^{C}{ }^{\mathrm{C}} \mathrm{K}_{\mathrm{D}}=56 \pm 9 \mu \mathrm{M}\right.$, Table 1) has a large repositioning of several sidechain oxygen ligands during $\mathrm{Ca}^{2+}$ coordination (EF-2: D61, D63, D65, E67, D69, and E72) [23, 24, 26, 34, 78, 87, 107-109]. Much like S100A1, S100A4, and S100A5, Asp-61 and Asp63, in positions 1 and 3 of the typical EF-hand, must rotate substantially to achieve a suitable $\mathrm{Ca}^{2+}$ binding orientation in S100B (Figures 2 and 4). That helix 4 is involved in the dimer interface explains why the entering helix 3 and not the exiting helix 4 moves significantly upon $\mathrm{Ca}^{2+}$ binding [23]. The conformational change, termed the "S100 $\mathrm{Ca}^{2+}-$ switch", is a feature unique to S100s and unlike other EFhand proteins (i.e., calmodulin and troponin C) in which position 12 reorients the exiting helix upon $\mathrm{Ca}^{2+}$ binding $[23,26,43,44,110,111]$. The conformational change of helix 3 involves breaking and forming hydrophobic contacts in several S100s with unique hydrophobic and/or hydrophilic residues becoming exposed for binding its protein target (Figures 2-4). However, S100A10 does not conform to other family members since it lacks a functional EF-hand $\mathrm{Ca}^{2+}$-binding domain, so its target protein interactions are all independent of $\mathrm{Ca}^{2+}[11,112]$. In several S100-target structures, much has been learned about specific target- and inhibitor-S100 interactions involving the "hinge (loop 2)", the C-terminal loop, and the hydrophobic pocket involving helices 3/4 for several S100s (site 1), a second surface, nearby helix 4 and the $\mathrm{Zn}^{2+}$ site in $\mathrm{S100B}$ (i.e., site 2) was also discovered more recently in drug design studies aimed at inhibiting S100B [20, 21].

However, several important aspects pertaining to the $\mathrm{Ca}^{2+}$ - and target-binding properties of S100s are not yet answered. With S100A5 and S100Z as exceptions ( ${ }^{\mathrm{Ca}} \mathrm{K}_{\mathrm{D}} \sim$ $0.2 \mu \mathrm{M}$, Table 1), dimeric S100s typically have a low affinity for binding $\mathrm{Ca}^{2+}$ in vitro $\left({ }^{\mathrm{Ca}} \mathrm{K}_{\mathrm{D}} \geq 1 \mu \mathrm{M}\right.$, EF2) $[10,124$, 134](Table 1), leading some to classifying this family of proteins as "calcium-buffers" while others predicted that S100s only bound $\mathrm{Ca}^{2+}$ in locations where $\mathrm{Ca}^{2+}$ ion concentrations were relatively high (endoplasmic reticulum and the extracellular space). While low in vitro binding affinities were first thought to eliminate a role for $\mathrm{S} 100 \mathrm{Ca}^{2+}$-binding in the cytosol, where $\left[\mathrm{Ca}^{2+}\right]_{\mathrm{i}}$ typically oscillates between 0.1 and $1 \mu \mathrm{M}[1,2]$, we now know that for many S100s, their $\mathrm{Ca}^{2+}$ binding affinity goes up significantly when its target protein is bound [34, 60, 109] (Figure 3). In fact, for S100A1 and the full-length ryanodine receptor (Figure 3(c)), the complex was detected at resting cytosolic $\left[\mathrm{Ca}^{2+}\right]_{\mathrm{i}}$ (i.e., at $100 \mathrm{nM}$ ) even though its $\mathrm{Ca}^{2+}$-binding affinity in vitro in the absence of target is $\sim 300$-fold higher $\left({ }^{\mathrm{Ca}} \mathrm{K}_{\mathrm{D}}=27 \pm 2 \mu \mathrm{M}\right.$ ) [60] (Table 1). One explanation for the tightening $\mathrm{Ca}^{2+}$-binding affinity is that target binding induces a structural change to provide a more optimal $\mathrm{Ca}^{2+}$-coordination geometry. Such an explanation was ruled out for S100B when the Xray structures of $\mathrm{Ca}^{2+}-\mathrm{S} 100 \mathrm{~B}( \pm$ TRTK12) and found that the $\mathrm{Ca}^{2+}$-coordination in both EF-hands $(\mathrm{EF} 1, \mathrm{EF} 2)$ was indistinguishable despite the fact that ${ }^{C a} k_{\text {off }}$ is $\sim 20$-fold slower when TRTK12 is bound [34]. Thus, the mechanism for "tightening" of $\mathrm{Ca}^{2+}$-binding with target bound cannot be explained by structural data alone. Interestingly, B-factors from X-ray structures (Figure 4) and ${ }^{15} \mathrm{~N}$ NMR relaxation rate studies of S100s have given us some indication that dynamic properties of S100 proteins are involved in the "tightening effect" (Figure 5). Thus, "induced-fit" versus "selected-fit" binding models for both the binding of $\mathrm{Ca}^{2+}$ and target to S100s have been considered. The underlying premise of the "selected-fit" model is that in the absence of target, the $\mathrm{Ca}^{2+}-\mathrm{S} 100$ complex observed in the X-ray structure is in equilibrium with a dynamic state(s) that has 
TABLE 1: Dissociation of $\mathrm{Ca}^{2+}$ and $\mathrm{Mn}^{2+}$ from the EF-hand calcium-binding domains in wild-type and mutant S100 proteins.

\begin{tabular}{|c|c|c|}
\hline S100 protein & EF1 & $\mathrm{EF} 2$ \\
\hline \multicolumn{3}{|l|}{$\mathrm{Ca}^{2+}$ binding } \\
\hline S100B (wt) & $>350 \mu \mathrm{M}^{\mathrm{a}, \mathrm{c}}$ & $56 \pm 9 \mu \mathrm{M}^{\mathrm{b}, \mathrm{c}}$ \\
\hline $\mathrm{S} 100 \mathrm{~B}(\mathrm{E} 31 \mathrm{~A})$ & $>500 \mu \mathrm{M}^{\mathrm{a}}$ & $>500 \mu \mathrm{M}^{\mathrm{a}}$ \\
\hline S100B (E72A) & $480 \pm 130 \mu \mathrm{M}^{\mathrm{a}}$ & $>500 \mu \mathrm{M}^{\mathrm{a}}$ \\
\hline $\mathrm{S} 100 \mathrm{~B}(\mathrm{E} 31 \mathrm{~A}+\mathrm{E} 72 \mathrm{~A})$ & $>2 \mathrm{mM}^{\mathrm{a}}$ & $>2 \mathrm{mM}^{\mathrm{a}}$ \\
\hline $\mathrm{S} 100 \mathrm{~B}(+\mathrm{p} 53)$ & - & $20 \pm 3 \mu \mathrm{M}^{\mathrm{a}}$ \\
\hline S100B (E31A, +p53) & - & $21 \pm 7 \mu \mathrm{M}^{\mathrm{a}}$ \\
\hline $\mathrm{S} 100 \mathrm{~B}(\mathrm{E} 72 \mathrm{~A},+\mathrm{p} 53)$ & - & $18 \pm 4 \mu \mathrm{M}^{\mathrm{a}}$ \\
\hline $\mathrm{S} 100 \mathrm{~B}(\mathrm{E} 31 \mathrm{~A}+\mathrm{E} 72 \mathrm{~A},+\mathrm{p} 53)$ & - & $>300 \mu \mathrm{M}^{\mathrm{a}}$ \\
\hline S100B (wt, +TRTK12) & - & $12 \pm 7 \mu \mathrm{M}^{\mathrm{c}}$ \\
\hline S100A1 (wt) & - & $27 \pm 2 \mu \mathrm{M}^{\mathrm{d}}$ \\
\hline S100A1 (wt, +TRTK12) & - & $8 \pm 3 \mu \mathrm{M}^{\mathrm{e}}$ \\
\hline $\mathrm{S} 100 \mathrm{~A} 2(\mathrm{wt})$ & - & $470 \pm 50 \mu \mathrm{M}^{\mathrm{f}}$ \\
\hline S100A3 (wt) & - & $\sim 4 \mathrm{mM}^{\mathrm{g}}$ \\
\hline S100A4 (wt) & - & $\sim 2.6 \mu \mathrm{M}^{\mathrm{h}}$ \\
\hline S100A4 (wt, +p37) & - & $\sim 0.2 \mu \mathrm{M}^{\mathrm{h}}$ \\
\hline S100A5 (wt) & $160 \mu \mathrm{M}^{\mathrm{i}}$ & $\sim 0.2 \mu \mathrm{M}^{\mathrm{i}}$ \\
\hline S100A6 (wt) & - & $\sim 3.0 \mu \mathrm{M}^{\mathrm{j}}$ \\
\hline S100A7 (wt) & - & $\sim 1.0 \mu \mathrm{M}^{\mathrm{k}, 1}$ \\
\hline S100A11 (wt) & - & $\sim 0.5 \mathrm{mM}^{\mathrm{m}}$ \\
\hline S100A12 (wt) & - & $\sim 50 \mu \mathrm{M}^{\mathrm{n}}$ \\
\hline S100A13 (wt) & $\sim 400 \mu \mathrm{M}$ & $\sim 8 \mu \mathrm{M}^{\mathrm{o}, \mathrm{p}}$ \\
\hline S100A16 (wt) & no binding & $0.43 \mathrm{mM}^{\mathrm{q}}$ \\
\hline S100P (wt) & $\sim 800 \mu \mathrm{M}$ & $\sim 2.0 \mu \mathrm{M}^{\mathrm{r}}$ \\
\hline S100Z (wt) & $>1 \mathrm{mM}$ & $\sim 0.2 \mu \mathrm{M}^{\mathrm{s}}$ \\
\hline \multicolumn{3}{|l|}{$M n^{2+}$ binding } \\
\hline S100B (wt) & - & $71 \pm 12 \mu \mathrm{M}^{\mathrm{a}, \mathrm{c}}$ \\
\hline S100B (wt, +p53) & - & $27 \pm 4 \mu \mathrm{M}^{\mathrm{a}, \mathrm{c}}$ \\
\hline S100B (wt, +TRTK12) & - & $6.0 \pm 2.0 \mu \mathrm{M}^{\mathrm{a}, \mathrm{c}}$ \\
\hline
\end{tabular}

a The value listed is from previously published papers [109, 113], so direct comparisons of binding constants using similar methods/conditions could be made (+/- target, Figure 3). Several others report binding constants using different methods and varying conditions for EF1 $\left(200 \mu \mathrm{M} \leq \mathrm{K}_{\mathrm{D}} \leq 500 \mu \mathrm{M}\right)$ and for EF2 $\left(10 \mu \mathrm{M} \leq \mathrm{K}_{\mathrm{D}} \leq 60 \mu \mathrm{M}\right)[58,78,86,87,114-120]$.

${ }^{b}$ The dissociation rate constant for wild-type $\mathrm{S} 100 \mathrm{~B}$ was determined via stopped-flow methods and is $\mathrm{k}_{\text {off }}=60 \pm 22 \mathrm{~s}^{-1}$. The off-rate together with the $\mathrm{K}_{\mathrm{D}}$ enables the calculation of a macroscopic on-rate value of $\mathrm{k}_{\mathrm{on}}=1.1 \times 10^{6} \mathrm{M}^{-1} \mathrm{~s}^{-1}$ that includes calcium-association plus a large conformational change. The $\mathrm{K}_{\mathrm{D}}$ value for the mutants was also determined using competition studies of $\mathrm{Ca}^{2+}$ with the respective $\mathrm{Tb}^{3+}$-bound S100B mutant in the absence and presence of p53 peptide. The dissociation constants together with the calcium off-rate values measured for the E31A and E72A mutants of $7.1 \pm 3.7 \mathrm{~s}^{-1}$ and $6.8 \pm$ $2.0 \mathrm{~s}^{-1}$, respectively, were sufficient to calculate on-rate values of $3.4 \pm 2.0 \times 10^{6} \mathrm{M}^{-1} \mathrm{~s}^{-1}$ and $3.7 \pm 1.3 \times 10^{6} \mathrm{M}^{-1} \mathrm{~s}^{-1}$ for the mutants [109, 113].

${ }^{\mathrm{c}}$ From Charpentier et al. (2010) [34].

${ }^{\mathrm{d}}$ From Wright et al. (2005) [61].

${ }^{e}$ From Wright et al. (2009) [59]. S100A1 has also been shown to bind the full-length ryanodine receptor at $100 \mathrm{nM}$ free $\mathrm{Ca}^{2+}[60,67]$.

${ }^{\mathrm{f}}$ From Franz et al. (1998) [89].

${ }^{\mathrm{g}}$ From Fritz et al. (1998). A tenfold weaker affinity was reported when purified under aerobic conditions [90, 121].

${ }^{h}$ From Dukhanina et al. (1998). A weaker affinity was reported under different conditions in Pedrocchi et al. (1994) when S100A4 was originally discovered $[122,123]$.

${ }^{\mathrm{i}}$ From Schäfer et al. (2000). For a direct comparison of $\mathrm{Ca}^{2+}$ and $\mathrm{Zn}^{2+}$ binding to S100A5 to those of other S100 proteins (i.e., S100B, S100A2, S100A3, S100A4, S1006, and S10011), under identical conditions and Methods, also see Schäfer et al., (2000) [124].

${ }^{j}$ From Kuznicki and Filipek (1987) and Mani and Kay (1990). Kordowska et al. also measured $\mathrm{Ca}^{2+}$-binding for S100A6 under different conditions $\left({ }^{\mathrm{Ca}} \mathrm{K}_{\mathrm{D}} \sim 18 \mu \mathrm{M}\right)$ and found that binding to the target caldesmon $(\mathrm{CaD})$ increased the affinity of S100A6 for Ca ${ }^{2+}$ by approximately 6-fold [96, 125, 126]. Other measurements under higher salt and other varying conditions are also reported with weaker affinities for S100A6 [68, 124].

${ }^{\mathrm{k}}$ From Schäfer et al. (2000) [124]. Weaker binding to $\mathrm{Ca}^{2+}$ has also been reported for this protein in other conditions [127].

${ }^{1}$ No data is available for S100A8/A9, and S100A10 does not bind $\mathrm{Ca}^{2+}$.

${ }^{m}$ From Allen et al. (1996) and Schäfer et al., $(2000)[124,128]$. Note the affinity for $\mathrm{Ca}^{2+}$ increases by 10 -fold upon the addition of a target molecule as found with other S100 proteins [128].

${ }^{n}$ From Dell'Angelica et al. (1994). Note that $\mathrm{Zn}^{2+}$-binding to S100A12 significantly increases $\mathrm{Ca}^{2+}$-binding affinity for this protein in the presence of $\mathrm{Zn}^{2+}$ $\left(\mathrm{EF} 2:{ }^{\mathrm{Ca}} \mathrm{K}_{\mathrm{D}}=40 \mathrm{nM}, \mathrm{EF} 1:{ }^{\mathrm{Ca}} \mathrm{K}_{\mathrm{D}}=15 \mu \mathrm{M}\right)[129]$.

${ }^{\circ}$ From Ridinger et al. (2000). This protein is unique among S100 family members in that it does not bind to the hydrophobic binding dye, TNS, upon the addition of $\mathrm{Ca}^{2+}[130]$.

PNo data is yet available for S100A14, and there is no S10015 [131].

qFrom Sturchler et al. (2006). The value in the table is for human S100A16, mouse S100A16 bound one calcium too, only weaker ( $\left.{ }^{\mathrm{Ca}} \mathrm{K}_{\mathrm{D}}=0.75 \mathrm{mM}\right)[132]$. ${ }^{\mathrm{r}}$ From Becker et al. (1992) and Gribenko et al., (1998) [92, 133]. In Gribenko et al., (1998), the effects of $\mathrm{Mg}^{2+}$ binding on Ca ${ }^{2+}$ affinity are also rigorously addressed. 
a lower $\mathrm{Ca}^{2+}$-binding affinity; when target protein binds to an $\mathrm{Ca}^{2+}-\mathrm{S} 100$ complex, the equilibrium shifts so "low affinity states" are eliminated when target binds to give less conformational exchange and an increase in measured $\mathrm{Ca}^{2+}$-binding (i.e., less free $\mathrm{Ca}^{2+}$, slower ${ }^{\mathrm{Ca}} \mathrm{k}_{\text {off }}$, Figure 3 ). Important for drug design, we found that S100B inhibitors can mimic target binding to also cause higher affinity $\mathrm{Ca}^{2+}$ binding (i.e., $\mathrm{K}_{\mathrm{D}}<1 \mu \mathrm{M}$ ). It is also now understood that weak $\mathrm{Ca}^{2+}$-binding for S100s in the absence of target may also turn out to be biologically relevant (Figure 1 ). Since most target-free S100s have low affinity for $\mathrm{Ca}^{2+}$, this allows numerous stable S100s to be at high concentrations in the cell $(>1 \mu \mathrm{M})$ without depleting $\left[\mathrm{Ca}^{2+}\right]_{\mathrm{i}}$ levels inside the cell and "short-circuiting" $\mathrm{Ca}^{2+}$ oscillations. Thus, several highly stable S100s can be "poised and ready" in any given cell for when their specific target(s) are expressed, as necessary for them to regulate numerous functions in mammalian cells (Figure 1) [109].

1.2. The S100 Model for Binding Calcium and Target. As a model system, $\mathrm{Ca}^{2+}$-dependent S100-target interactions are attractive, since S100s, in essence, have only one "functional" EF-hand (EF2, Figure 2) per subunit, which for S100B does not cooperate with the EF1 or EF1 ${ }^{\prime} / \mathrm{EF} 2^{\prime}$ of the other subunit in $\mathrm{Ca}^{2+}$-binding $[10,23,31,78,87,109]$. This is very much unlike calmodulin (CaM) and troponin $\mathrm{C}(\mathrm{TnC})$, which have several functional and highly cooperative EFhand $\mathrm{Ca}^{2+}$-binding domains [66]. Thus, a typical dimeric S100-target interaction is $\mathrm{Ca}^{2+}$-dependent and involves at least 11 possible states, 13 dissociation constants $\left(K_{1}-K_{13}\right)$, four conformational changes $\left(\mathrm{L}_{1}-\mathrm{L}_{4}\right)$, and the corresponding rate constants $\left(\mathrm{k}_{1}-\mathrm{k}_{17}, \mathrm{k}_{-1}-\mathrm{k}_{-17}\right)$, per symmetric subunit [109] (Figure 5). As for $\mathrm{Ca}^{2+}$-binding, the conformational changes and the binding events for a single target are also symmetric and occur independently of those on the other subunit (i.e., without cooperativity), so only one S100 subunit needs to be considered in the thermodynamic scheme $[10,23,31,78,87,109]$. At low $\left[\mathrm{Ca}^{2+}\right]$ (Figure 5), the predominant kinetic pathway for target binding to S100s can be simplified to $\mathrm{K}_{\mathrm{I}}\left(\mathrm{k}_{-1} / \mathrm{k}_{1}\right.$, step 1$), \mathrm{L}_{1}\left(\mathrm{k}_{-14} / \mathrm{k}_{14}\right)$, and $\mathrm{K}_{\mathrm{X}}\left(\mathrm{k}_{-10} / \mathrm{k}_{10}\right.$, step 2$)$ because an $\mathrm{S} 100$ - or pseudo-EF-hand motif (EF1) binds $\mathrm{Ca}^{2+}$ about an order of magnitude more weakly than EF2 $\left(\mathrm{K}_{\mathrm{I}} \ll \mathrm{K}_{\mathrm{II}}\right.$, i.e., $\left.\mathrm{K}_{\mathrm{II}} \sim 0.5 \mathrm{mM}\right)$ [109]. However, in addition to a two-step $\mathrm{K}_{\mathrm{I}} \cdot \mathrm{L}_{1} \cdot \mathrm{K}_{\mathrm{X}}$ pathway for target binding, we will also consider three additional equilibriums resulting from conformational exchange prior to $\mathrm{Ca}^{2+}$ binding $\left(\mathrm{K}_{\mathrm{XIV}}\right)$, prior to target binding $\left(\mathrm{K}_{\mathrm{XV}}\right)$, as well as for the S100-target bound state (KXIV, Figure 5, Scheme 1). In step 1 (Scheme 1), structural data provides support for the "induced-fit" aspect of $\mathrm{Ca}^{2+}$ binding to S100B (i.e., A $\left.+\mathrm{Ca}^{2+} \leftrightarrow\left[\mathrm{A}-\mathrm{Ca}^{2+}\right]^{\ddagger} \leftrightarrow \mathrm{B}-\mathrm{Ca}^{2+}\right)$ since the apoS100B (state A) has a patch of negatively charged residues comprising residues in the typical EF-hand (D65, E67, D69, and E72) sufficient for a fast bimolecular interaction with $\mathrm{Ca}^{2+}[23,24]$. Furthermore, no conformational exchange $\left(\mathrm{R}_{\mathrm{ex}}\right)$ has yet been observed in ${ }^{15} \mathrm{~N}$-relaxation rate $\mathrm{NMR}$ studies of apo-S100B for any residues in helix 3 or in either of the $\mathrm{Ca}^{2+}$-binding loops that subsequently undergo structural transitions when $\mathrm{Ca}^{2+}$ is added [136]. However, this needs to be examined more rigorously for apo-S100B and for other apo-S100s using ZZ-exchange and relaxation dispersion NMR methods (off-resonance $\mathrm{R}_{1 \rho}$, rcCPMG). Nonetheless, the lack of detectable $\mathrm{R}_{\mathrm{ex}}$ in the apo-state currently provides an argument against the $\mathrm{A} \leftrightarrow \mathrm{B}$ conversion (via $\mathrm{K}_{\mathrm{XIV}}$ ) (Figure 5, Scheme 1, in green). In step 2, for target binding to an $\mathrm{S} 100$ (i.e., $\mathrm{B}-\mathrm{M}_{\mathrm{II}}+\mathrm{S} \leftrightarrow \mathrm{B}-\mathrm{M}_{\mathrm{II}}-\mathrm{S}$, via $\mathrm{K}_{\mathrm{X}}$ ), NMR data does exhibit $\mathrm{R}_{\mathrm{ex}}$ for both $\mathrm{Ca}^{2+}-\mathrm{S} 100 \mathrm{~B}$ and $\mathrm{Ca}^{2+}$ S100A1 [59, 60, 77, 136, 137]; these preliminary data are consistent with a model in which target binding selects a competent conformation(s) from an ensemble of dynamic states (via $K_{X V}$, i.e., "selected-fit" model [138]). The selectedfit hypothesis is also supported by the loss of exchange broadening upon binding of $\mathrm{p} 53$ and other targets to $\mathrm{Ca}^{2+}$ S100B [77, 113]. Further, the rate of $\mathrm{Ca}^{2+}$ dissociation ( ${ }^{\mathrm{Ca}} \mathrm{k}_{\text {off }}$ ) from EF2 decreases from $60 / \mathrm{s}$ to $7 / \mathrm{s}$ when p53 binds as measured by stopped-flow methods [109]; similar results were found when other targets, including an S100B inhibitor (SBi1) bound to $\mathrm{Ca}^{2+}-\mathrm{S} 100 \mathrm{~B}$ (Cannon and Weber, unpublished results). We now have X-ray crystal structures of S100B-Ca ${ }^{2+}$ and S100B-Ca ${ }^{2+}-$ TRTK12 that show $\mathrm{Ca}^{2+}$ coordination is indistinguishable in the two complexes [34], whereas, elevated B-factors were observed for S100B-Ca ${ }^{2+}$ for residues in EF2 in the absence of bound target (Figure 4). One interpretation of the elevated B-factors is that there is conformational dynamics affecting EF2 in the absence of target, however, other explanations cannot be ruled out such as the possibility that lattice contacts are different in the two structures giving rise to the changes in B-factors [34]. Thus, it is important to further examine the dynamics of $\mathrm{Ca}^{2+}$ S100s, including EF2, directly by NMR to determine whether the decreased B-factors in EF2 (Figure 4) were due to a loss of conformational exchange as represented in Figure 5.

Additional evidence supporting Scheme 1 (Figure 5) is from stopped-flow experiments with $\mathrm{S} 100-\mathrm{Ca}^{2+}$ and S100B$\mathrm{Ca}^{2+}$-target complexes [109]. Here, a fast kinetic-step at the earliest time points in stopped-flow traces has been observed (i.e., biphasic, Cannon and Weber, unpublished results), indicative of $\mathrm{K}_{X V}$. Also satisfying is that $\mathrm{K}_{\mathrm{XV}}$ in Figure 5 provides a means for a single S100 protein to sample conformational space (i.e., at $\mathrm{BM}_{\mathrm{II}}$ ), as may be necessary to bind more than one target protein, an observation made for several S100 proteins [10]. Structurally similar S100 proteins may also bind the same protein target (i.e., TRTK12), although $\mathrm{k}_{\text {off }}$ (i.e., $\mathrm{k}_{-10}$ ) in these cases usually varies due to specific differences in the binding site that give S100-target protein complexes unique conformations and hence varying "lifetimes" inside the cell (i.e., different ${ }^{\mathrm{Ca}} \mathrm{k}_{\text {off }}$ values). These issues regarding specificity are important and require further examination. It is also necessary to remember that one assumption in this model (Figure 5) is that binding of $\mathrm{Ca}^{2+}$ to $\mathrm{EF} 1$ is not significant. While this assumption is valid based on existing $K_{D}$ values (and verified for S100B) [87]), weak $\mathrm{Ca}^{2+}$ binding to this EF-hand (EF1) in other S100s may slightly populate additional states, which together with cooperative binding effects observed in some cases [15] could complicate interpretations with this simple model (Figure 5). 


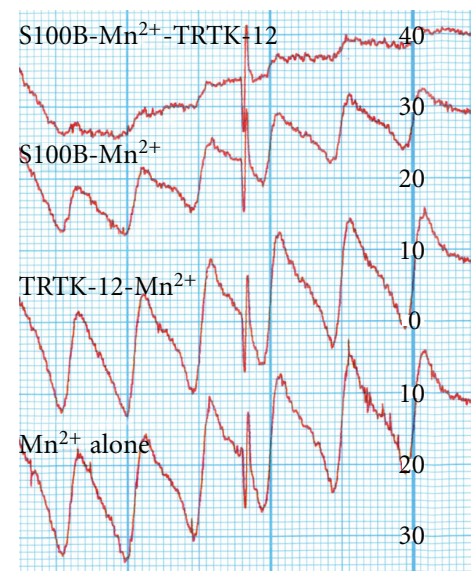

(a)

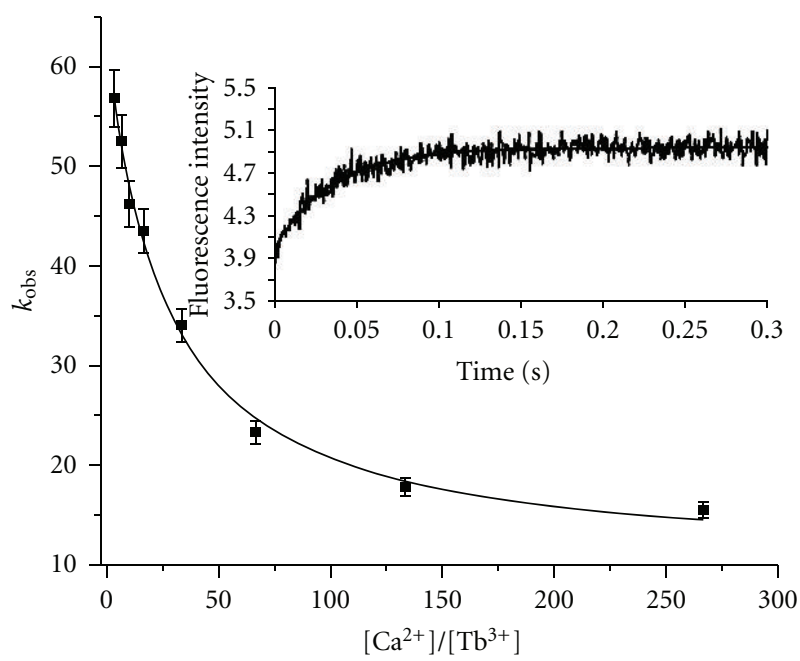

(b)

$100 \mathrm{nM} \mathrm{Ca}^{2+}$

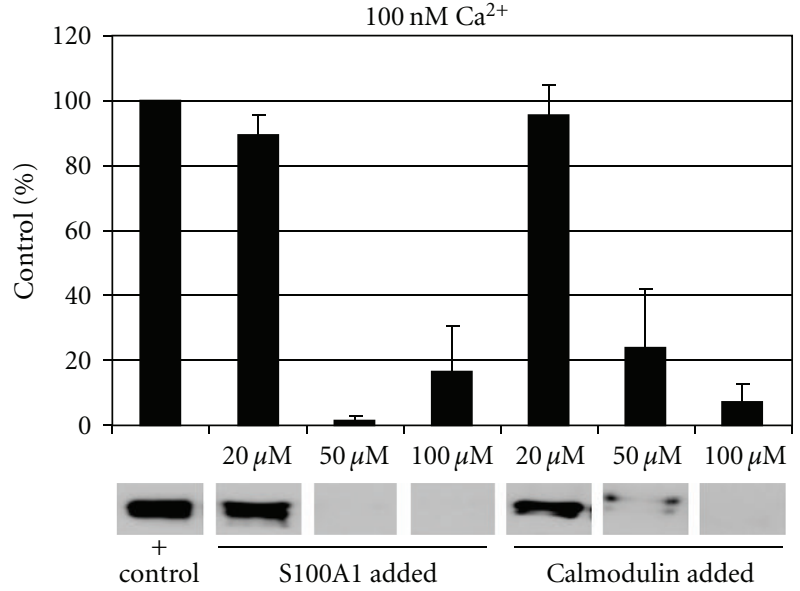

(c)

FIGURE 3: Metal ion and target binding properties of S100 proteins. (a) Binding studies with $\mathrm{Mn}^{2+}$ were completed since it is a good probe of the high affinity $\mathrm{Ca}^{2+}$ binding site on S100B (EF2) $[113,135]$. Free $\mathrm{Mn}^{2+}$ was measured by electron paramagnetic resonance (EPR) in the absence and presence of S100B (+/- target peptide TRTK12) [34]. In all four traces, total $\left[\mathrm{Mn}^{2+}\right]$ is identical $(80 \mu \mathrm{M})$ with the bottom trace (4th trace) showing the signal for total $\left[\mathrm{Mn}^{2+}\right]$. TRTK12 alone $(1 \mathrm{mM})$ has no effect on the EPR signal (3rd trace), whereas, the addition of S100B $(65 \mu \mathrm{M})$ binds $\mathrm{Mn}^{2+}$ and reduces free $\left[\mathrm{Mn}^{2+}\right.$ ] (2nd trace). The addition of the same amount of S100B (65 $\left.\mu \mathrm{M}\right)$ plus TRTK12 (1 mM, top trace) has the least free $\left[\mathrm{Mn}^{2+}\right]$ and indicates that TRTK12 binding to S100B- $\mathrm{Mn}^{2+}$ enhances $\mathrm{Mn}^{2+}$ binding (compare traces 1 and 2 ). A similar effect was observed for SBil (unpublished) and for p53 $3^{367-388}$ [109]. As for p53 $3^{367-388}$ and SBil, TRTK12 increased the affinity of S100B for $\mathrm{Ca}^{2+}$ in competition studies with $\mathrm{Mn}^{2+}$ and via stopped-flow kinetic measurements of ${ }^{\mathrm{Ca}} \mathrm{k}_{\text {off }}$ as monitored in competition with $\mathrm{Tb}^{3+}$. (b) Plot of the decrease in $\mathrm{k}_{\mathrm{obs}}$ as a function of $\left[\mathrm{Ca}^{2+}\right] /\left[\mathrm{Tb}^{3+}\right]$ as used to determine the off rate of $\mathrm{Ca}^{2+}$ from the 2nd EF-hand (EF2, $\left.{ }^{\mathrm{Ca}} \mathrm{k}_{\text {off }}\right)$. The $\mathrm{k}_{\mathrm{obs}}$ values at each $\left[\mathrm{Ca}^{2+}\right] /\left[\mathrm{Tb}^{3+}\right]$ ratio were calculated from kinetic traces of stopped-flow experiments where Tb ${ }^{3+}($ syringe $\mathrm{C})$ is mixed with $\mathrm{S} 100 \mathrm{~B}$ at varying $\mathrm{Ca}^{2+}$ concentrations (syringe $\mathrm{A}$ ) and $\left[\mathrm{Tb}^{3+}\right]$ signal is monitored as a function of time $\left(\lambda_{\mathrm{ex}}=230 \mathrm{~nm}, \lambda_{\mathrm{em}}=\right.$ $545 \mathrm{~nm})$. A ${ }^{\mathrm{Ca}} \mathrm{k}_{\text {off }}$ of $60 \pm 8 / \mathrm{sec}$ was calculated from these experiments with S100B alone. When either TRTK12 or SBil is present, then the calculated ${ }^{\mathrm{Ca}} \mathrm{k}_{\text {off }}$ value for S100B is reduced to $5 \pm 3 / \mathrm{sec}$ similar to that found for p53367-388 [109]. These studies demonstrated that TRTK12, p53 ${ }^{367-388}$, or SBil increased the affinity of S100B for $\mathrm{Ca}^{2+}$ at least in part by decreasing ${ }^{\mathrm{Ca}} \mathrm{k}_{\mathrm{off}}$. In (c), S100A1 was found to bind the full length ryanodine receptor (RyR) at $100 \mathrm{nM}$ free calcium. Specifically, S100A1 competed full-length RyR1 away from agarose-linked CaM beads as judged by a decreased RyR1 band in an anti-RyR Western blot. Free CaM, a positive control, also competed the RyR away from CaM-linked beads $[60,67]$.

\subsection{S100 Family Members Exhibit Overlapping but Distinct} Target Protein Binding Profiles. While structural, biochemical, and biophysical approaches yield important structural and mechanistic details, they cannot be used to screen simultaneously the interaction of multiple S100 family members with an extensive array of full-length target proteins. Therefore, we developed a quantitative assay that monitors the interaction of fluorophore labeled S100s with membraneimmobilized target proteins that could be used to efficiently identify/prioritize S100-target protein interactions and S100 


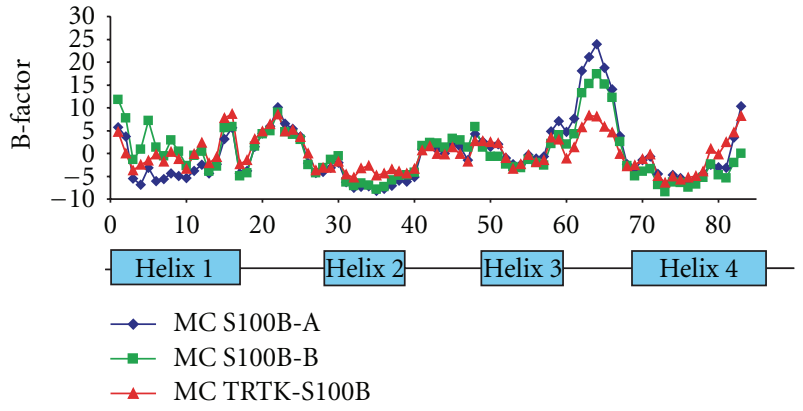

(a)

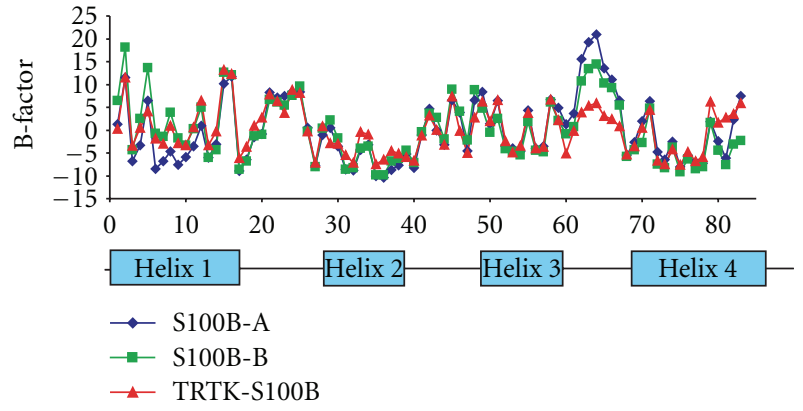

(b)

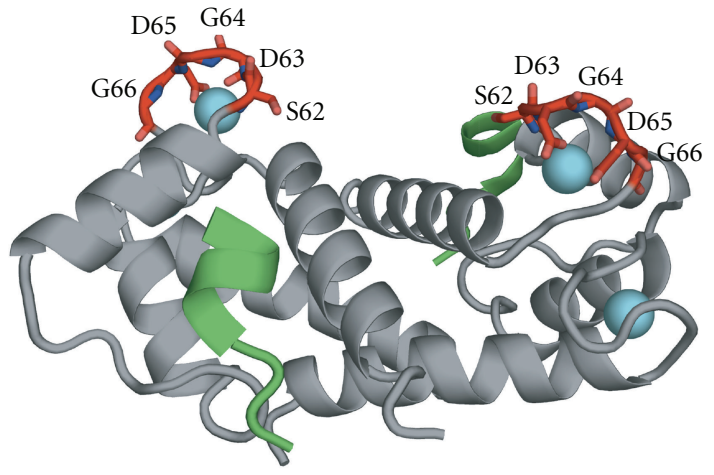

(c)

FIgURE 4: B-factors for X-ray structures of TRTK12-Ca ${ }^{2+}-S 100 B(2.0 \AA)$ and $C a^{2+}-S 100 B$ (1.5 $\AA$ ) from the PI's laboratory. (a) B-factors for backbone atoms for each subunit of $\mathrm{Ca}^{2+}-\mathrm{S} 100 \mathrm{~B}$ (blue, green) and for TRTK-Ca ${ }^{2+}-\mathrm{S} 100 \mathrm{~B}$ (red). (b) B-factors for sidechains with symbols as in (a). (c) Also shown is a ribbon diagram of the TRTK12-Ca ${ }^{2+}-\mathrm{S} 100 \mathrm{~B}$ structure with residues colored red in EF2 (residues 61-72), which display lower B-factors in the TRTK12-bound state (in panels (a) and (b)). These data are all published in Charpentier et al., 2010 [139].

domains for structural/mechanistic analyses. First, commercially available Alexa-Fluor 488-conjugated calmodulin (CaM-488) and two well-characterized calmodulin target proteins, calmodulin-dependent kinase II (CaM kinase II) and phosphorylase kinase, were used to determine if this methodology would yield data representative of published $\mathrm{K}_{\mathrm{D}} \mathrm{s}$ and $\mathrm{K}_{\mathrm{A}} \mathrm{s}$ (Figure 6). The interaction of CaM-488 with both target proteins was $\mathrm{Ca}^{2+}$ dependent. Immobilized $\mathrm{CaM}$ kinase II bound 5.4 pmoles CaM-488 in the presence of $\mathrm{Ca}^{2+}$ and 0.1 pmoles CaM-488 in the absence of $\mathrm{Ca}^{2+}$. Similarly, immobilized phosphorylase kinase bound 0.7 pmoles CaM488 in the presence of $\mathrm{Ca}^{2+}$ and 0.3 pmoles CaM-488 in the absence of $\mathrm{Ca}^{2+}$. Furthermore, the 8 -fold difference in bound CaM-488 ( 5.4 versus 0.7 pmoles) is in qualitative agreement with the higher affinity reported for CaM kinase II when compared to phosphorylase kinase [140, 141]. These data demonstrate the feasibility of using a membrane binding assay and Alexa-Fluor conjugated $\mathrm{Ca}^{2+}$-receptor proteins to monitor $\mathrm{Ca}^{2+}$ dependency of target protein interactions and to qualitatively compare the binding interaction.

To verify that this methodology could also be used to monitor S100-target protein interactions, the binding of S100A1-488 to a previously characterized target protein, glycogen phosphorylase a, was evaluated [73]. Consistent with results of previous gel overlay and affinity chromatography experiments, S100A1-488 exhibited $\mathrm{Ca}^{2+}$-dependent binding to immobilized glycogen phosphorylase a at all points (Figure 7). Furthermore, S100A1-488 binding was saturable with a $\mathrm{B}_{\max }$ of 30.0 pmoles and $\mathrm{EC}_{50}$ for binding value of 37.5 pmoles. While this type of assay does not provide a $\mathrm{K}_{\mathrm{D}}$, the $\mathrm{B}_{\max }$ and $\mathrm{EC}_{50}$ can be used to compare S100-target protein interactions. Nonetheless, full-binding curves do not permit the simultaneous characterization of multiple S100s interacting with numerous target proteins. Therefore, two targets which exhibit differential interactions with S100A1 and S100B were used to determine if a single point assay like the one used in Figure 6 to characterize CaM target protein interactions would accurately reflect S100 target protein interactions. The quantity of target protein (50 pmoles) and probe concentration (100 nM S100A1-488 or $\mathrm{S} 100 \mathrm{~B}-488$ ) were based on the $\mathrm{EC}_{50}$ ( $\sim 40$ pmoles) for glycogen phosphorylase a in 100 nM S100A1-488 (Figure 8). S100A1-488 and S100B-488 exhibited $\mathrm{Ca}^{2+}$-dependent binding to phosphoglucomutase as well as glycogen phosphorylase, and the range of binding was similar to that observed for CaM target proteins. Glycogen phosphorylase a and b bound similar amounts of S100A1-488 (12-15 pmoles) and S100B-488 (15-20 pmoles). In contrast, phosphoglucomutase bound 5-fold more S100B-488 (14 pmoles) than S100A1-488 (2 pmoles). This differential binding was undetectable in previous gel overlay and affinity chromatography experiments despite the differential effects of S100A1 and S100B on phospohglucomutase activity [142]. The insensitivity/inability of the overlay and affinity chromatography 


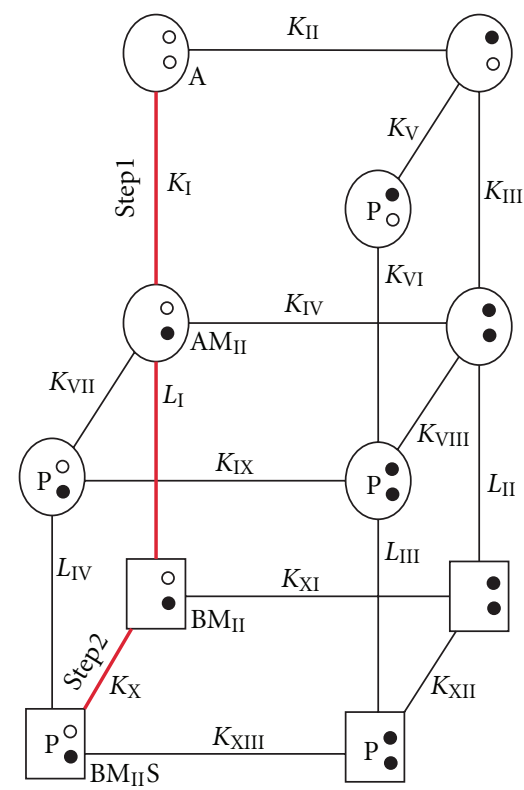

FIGURE 5: Models for $\mathrm{Ca}^{2+}$-binding and then target-binding to an S100 protein. (Top) A model for the Ca ${ }^{2+}$-dependent interaction of S100B with target proteins involves 13 equilibrium constants $\left(\mathrm{K}_{\mathrm{I}}\right.$ to $\left.\mathrm{K}_{\mathrm{XIII}}\right)$, 11 states, and 4 conformational changes $\left(\mathrm{L}_{\mathrm{I}}-\mathrm{L}_{\mathrm{IV}}\right)$ [109]. The most highly populated states and the predominant pathway are colored red; this is due to weak $\mathrm{Ca}^{2+}$ binding in the pseudo-EF-hand (site I), which greatly simplifies this model (see Scheme 1). Specifically, the binding of $\mathrm{Ca}^{2+}$ to the pseudo- and typical EF-hand in each S100B subunit is described by six states $\left(\mathrm{A}, \mathrm{AM}_{\mathrm{I}}, \mathrm{AM}_{\mathrm{II}}, \mathrm{AM}_{\mathrm{I}} \mathrm{M}_{\mathrm{II}}, \mathrm{BM}_{\mathrm{I}}\right.$, and $\left.\mathrm{BM}_{\mathrm{II}}\right)$, five equilibrium constants $\left(\mathrm{K}_{\mathrm{I}}=[\mathrm{A}][\mathrm{M}] /\left[\mathrm{AM}_{\mathrm{I}}\right], \mathrm{K}_{\mathrm{II}}=[\mathrm{A}][\mathrm{M}] /[\mathrm{AM} \mathrm{II}], \mathrm{K}_{\mathrm{III}}=\right.$ $\left[\mathrm{AM}_{\mathrm{I}}\right][\mathrm{M}] /\left[\mathrm{AM}_{\mathrm{I}, \mathrm{II}}\right], \mathrm{K}_{\mathrm{IV}}=\left[\mathrm{AM}_{\mathrm{II}}\right][\mathrm{M}] /\left[\mathrm{AM}_{\mathrm{I}, \mathrm{II}}\right]$, and $\mathrm{K}_{\mathrm{XI}}=\left[\mathrm{BM}_{\mathrm{II}}\right][\mathrm{M}] /\left[\mathrm{BM}_{\mathrm{I}, \mathrm{II}}\right]$, two conformational changes $\left(\mathrm{L}_{\mathrm{I}}: \mathrm{AM}_{\mathrm{II}} \leftrightarrow \mathrm{BM}_{\mathrm{II}}, \mathrm{L}_{\mathrm{II}}: \mathrm{AM}_{\mathrm{I}, \mathrm{II}} \leftrightarrow\right.$ $\mathrm{BM}_{\mathrm{I}, \mathrm{II}}$ ) with corresponding rate constants, respectively, where $\mathrm{A}=\mathrm{S} 100 \mathrm{~B}$ prior to the $90^{\circ}$ reorientation of helix three of $\mathrm{S} 100 \mathrm{~B}, \mathrm{~B}=\mathrm{S} 100 \mathrm{~B}$ after $90^{\circ}$ reorientation of helix three, $\mathrm{M}_{\mathrm{I}}=\mathrm{a} \mathrm{Ca}^{2+}$ ion bound to EF-hand I (pseudo-EF-hand), $\mathrm{M}_{\mathrm{II}}=\mathrm{a} \mathrm{Ca}^{2+}$ ion bound to EF-hand II (typical EF-hand), $\mathrm{M}_{\mathrm{I}, \mathrm{II}}=\mathrm{Ca}^{2+}$ ions bound to EF-hand I and EF-hand II. Upon the addition of p53 or another target (S), the model expands to 11 possible states, 13 dissociation constants, and four possible conformational changes. Whether additional equilibriums occur (KXIV, $\mathrm{K}_{\mathrm{XV}}$, and $\mathrm{K}_{\mathrm{XVI}}$ ) is considered in Scheme 1. (Bottom) In a second model (Scheme 1), state A is defined as the "closed" conformation observed in the apo-state (Figure 2), and state B is after a $90^{\circ}$ reorientation of helix 3 termed the "open" conformation. In black, are states hypothesized to be populated. $\left[\mathrm{A}-\mathrm{M}_{\mathrm{II}}\right]^{\ddagger}$ and $\left[\mathrm{B}-\mathrm{M}_{\mathrm{II}}\right]^{\ddagger}$ represent short-lived intermediates, and $\mathrm{L}_{1}$ is the $\mathrm{Ca}^{2+}$-dependent conformational change involving helix 3 of S100B upon binding $\mathrm{Ca}^{2+}$ (Figure 2). Based on NMR relaxation rate data from the PI's lab [136], KXIV highly favors state A. States are also considered via $\mathrm{K}_{\mathrm{XV}}$ and $\mathrm{K}_{\mathrm{XVI}}$ which result in $\mathrm{B}^{*}$ states that represent an ensemble of dynamic structures, of which, only a subset fully coordinate $\mathrm{Ca}^{2+}$ as observed in X-ray structures [9]. It is hypothesized that $\mathrm{K}_{\mathrm{XV}}$ favors the $\mathrm{B}^{*} \mathrm{M}_{\mathrm{II}}$ state(s), whereas, $\mathrm{K}_{\mathrm{XVI}}$ favors $\mathrm{B}-\mathrm{M}_{\mathrm{II}}-\mathrm{S}$, explaining the apparent increase in $\mathrm{Ca}^{2+}$-binding affinity using equilibrium binding measurements that monitor free [metal ion] (Figure 3 ).

\begin{tabular}{|c|c|c|c|c|c|c|}
\hline \multicolumn{3}{|c|}{ Step 1} & & \multicolumn{3}{|c|}{ Step 2} \\
\hline$A+M$ & $\stackrel{K_{\mathrm{I}}}{\longleftrightarrow}$ & {$\left[\mathrm{A}-\mathrm{M}_{\mathrm{II}}\right]^{++}$} & $\stackrel{k_{14}}{\stackrel{k_{10}}{(2)}}$ & $\mathrm{B}-\mathrm{M}_{\mathrm{II}}+\mathrm{S}$ & $\stackrel{K_{\mathrm{X}}}{\longleftrightarrow}$ & B-M $\mathrm{M}_{\mathrm{II}}-\mathrm{S}$ \\
\hline$K_{\mathrm{XIV}} \uparrow \downarrow$ & & $\uparrow \downarrow$ & & $K_{\mathrm{XV}} \uparrow \downarrow$ & & $K_{\mathrm{XVI}} \uparrow \downarrow$ \\
\hline$B+M$ & $\longleftrightarrow$ & {$\left[\mathrm{B}-\mathrm{M}_{\mathrm{II}}\right]^{++}$} & $\longleftrightarrow$ & $\mathrm{B}^{*} \mathrm{M}_{\mathrm{II}}+\mathrm{S}$ & $\hookrightarrow$ & $\mathrm{B}^{*} \mathrm{M}_{\mathrm{II}}-\mathrm{S}$ \\
\hline
\end{tabular}

Scheme 1

experiments to detect differential binding is most likely attributable to the high levels of receptor and/or ligand present. Altogether, these results demonstrate that a single point fluorometric assay can be used to quickly assess the relative affinity and $\mathrm{Ca}^{2+}$-dependency of $\mathrm{S} 100$-target protein interactions.

Next, we compared the ability of different $\mathrm{S} 100$ family members (S100A1, S100A4, S100A5, and S100P) to interact with four previously reported S100B targets, glycogen phosphorylase a, glycogen phosphorylase $\mathrm{b}$, tau, and phosphoglucomutase (Figure 8). As expected, all four target proteins bound S100B-488 (10-35 pmoles) in a $\mathrm{Ca}^{2+}$-dependent manner. While none of the other family members exhibited the same target protein binding profile as $\mathrm{S100B}$, there did appear to be two distinct groups: one group (S100A1 and S100P) with profiles that were similar to and another group (S100A4 and S1005) that clearly distinct from S100B. Glycogen phosphorylase $\mathrm{a}$ and $\mathrm{b}$ bound similar levels of S100A1-488/S100P-488. However, phosphoglucomutase did not bind S100P-488 and 6-fold less S100A1-488 when compared to $\mathrm{S100B}-488$. In addition, tau bound $>10$ fold less S100P-488 than S100B-488 and binding to S100A1-488 was $\mathrm{Ca}^{2+}$ independent. In the case of S100A4 and S1005, binding to all target proteins was below 10 pmoles. Finally, labeled S100A1, S100B, S100A4, and CaM (100 nM) did not bind to immobilized S100 family members (S100A1, S100B, S100A2, S100A4, S100A5, S100A11, and S100A13), calmodulin, or 
the negative control $\alpha$-lactalbumin (75 pmoles) in the presence or absence of $\mathrm{Ca}^{2+}$ (data not shown). Collectively these data demonstrate that while there is extensive overlap among S100 family members with regard to the target proteins that they interact with, each S100 interacts with a unique compliment of target proteins. Nonetheless, there do appear to be family member-specific target proteins. For example, phospohglucomutase preferentially interacts with S100B. Furthermore, the relative affinity and $\mathrm{Ca}^{2+}$ dependency of the interaction can vary among family members. For example, tau is a target protein for multiple S100s including S100A1, S100A4, S100A5, and S100P, but only the interaction of tau with $\mathrm{S} 100 \mathrm{~B}$ is $\mathrm{Ca}^{2+}$-dependent.

\subsection{The Linker Region Mediates Family Member-Specific} Binding. The linker region, the amino acid sequence that links the two EF-hands, exhibits the greatest sequence diversity among family members and has been postulated to regulate family member-specific binding to target proteins such as phosphoglucomutase. Consistent with this hypothesis is the accessibility of this region to solvent in both the apo- and $\mathrm{Ca}^{2+}$-bound states of all family members for which $3 \mathrm{D}$ structures are available $[10,23$, 57, 143]. To test this hypothesis, we checked the ability of a recombinant S100B-A1-B chimeric protein to bind to target proteins, in which the $\mathrm{S} 100 \mathrm{~B}$ linker region was replaced with comparable amino acid sequence from S100A1 (Figure 8). This chimeric protein was readily purified using similar procedures as used previously for S100B/S100A1, and the mutations to the hinge region did not exhibit any altered biochemical or biophysical properties tested. As anticipated, the interaction of the fluorophore-labeled chimeric protein with the S100A1/S100B targets glycogen phosphorylase $\mathrm{a}$ and $\mathrm{b}$ was indistinguishable from that of S100A1-488 and S100B-488, that is, $\mathrm{Ca}^{2+}$-dependent binding in the 10-25 pmole range. In contrast, phosphoglucomutase, a target protein that preferentially interacts with S100B, bound 2-4-fold less S100B-A1-B-488 when compared to S100B-488. Interestingly, the presence of the S100A1 linker region did not lower and/or reverse the $\mathrm{Ca}^{2+}$-dependent interaction with tau. Additional experiments will be needed to ascertain the linker region's contribution to other familymember specific target protein interactions as well as $\mathrm{Ca}^{2+}$ independent target protein binding. Nonetheless, this is the first demonstration that the linker region does confer familyspecific binding for some $\mathrm{Ca}^{2+}$-dependent target proteins.

\subsection{The $\mathrm{Ca}^{2+}$-Dependent Target Protein Binding Domain.} Carboxyl terminal aromatic residues (Phe88, Phe89, Trp90) of S100A1 have been previously shown to regulate $\mathrm{Ca}^{2+}$ dependent interaction of S100A1 with the TRTK peptide, GFAP, and tubulin [72, 144, 145]. Analogous residues are found in several other members including S100B, S100A4, and S100A10 [78, 146-149]. To determine if these residues are obligatory for $\mathrm{Ca}^{2+}$-dependent target protein interactions, we examined the interaction of the S100A1 (F88/89AW90A)-488 with four additional S100A1 target proteins (Figure 9). As anticipated, mutant S100A1 binding to all four

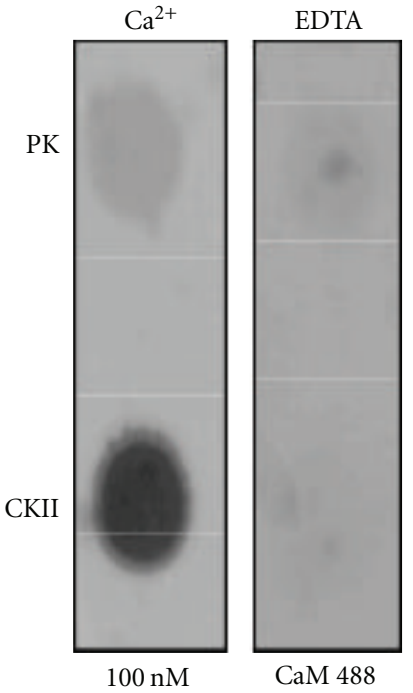

(a)

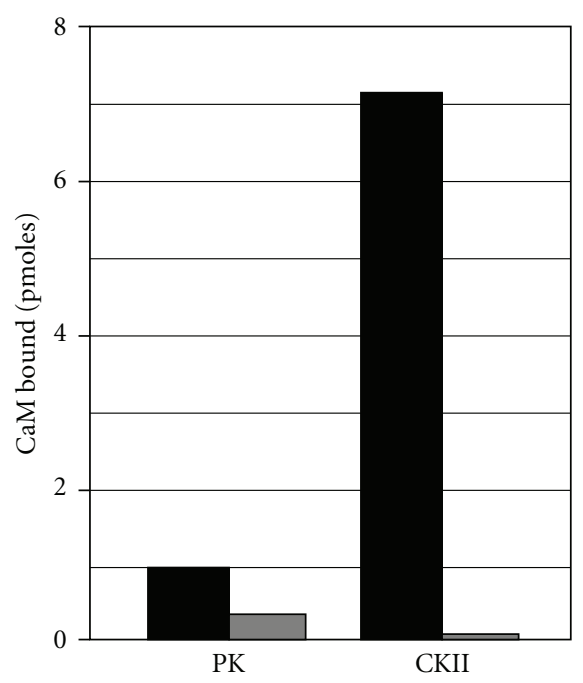

(b)

FIGURE 6: Characterization of CaM-488 target protein binding. Equimolar concentrations of CaM kinase II (CKII) phosphorylase kinase $(\mathrm{PK})$ were immobilized on a PVDF membrane and incubated with $100 \mathrm{nM}$ CaM-488 in the presence of $\mathrm{Ca}^{2+}$ or EDTA. Panel A contains a representative dot blot image. The histograms in Panel $\mathrm{B}$ represent the mean pmoles CaM-488 bound in the presence (black bars) and absence (gray bars) of $\mathrm{Ca}^{2+}$ assayed in triplicate in two independent experiments. Consistent with reported $\mathrm{K}_{\mathrm{d}} \mathrm{s}$ and $\mathrm{K}_{\mathrm{a}} \mathrm{s}$, both targets exhibited $\mathrm{Ca}^{2+}$-dependent binding with the higher affinity target, CKII, binding more CaM-488 (7.0 pmoles) when compared to the lower affinity target PK (0.8 pmoles).

target proteins was decreased by $\sim 4$-fold in the presence of $\mathrm{Ca}^{2+}$. Interestingly, there was a 4-fold increase in mutant S100A1 binding to tau in the absence of $\mathrm{Ca}^{2+}$. These results confirm that carboxy-terminal aromatic residues contribute to the $\mathrm{Ca}^{2+}$-dependent interaction of S100s with protein targets. However, it is not the only mechanism because not all family members that exhibit $\mathrm{Ca}^{2+}$-dependent target protein 


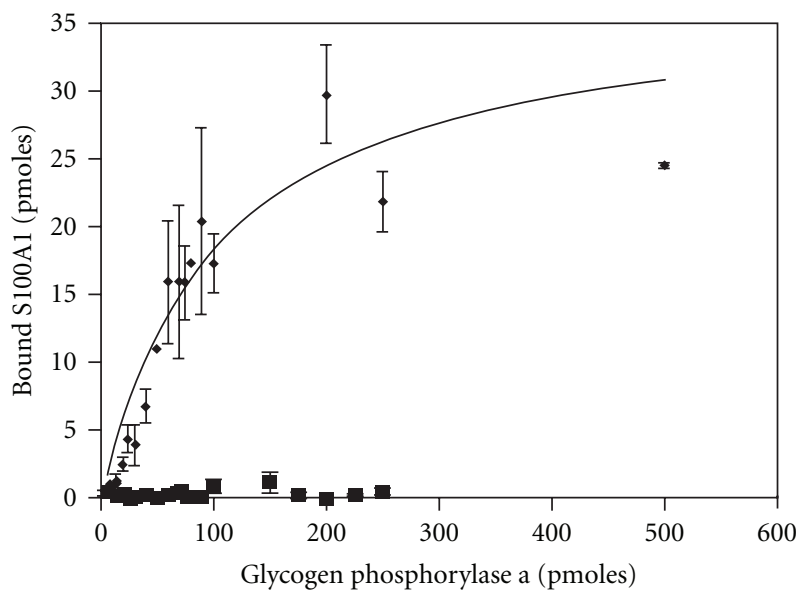

Figure 7: S100A1-488 binding curves for glycogen phosphorylase a. Membranes containing varying concentrations of glycogen phosphorylase were incubated in S100A1-488 in the presence $(\bullet)$ or absence $(\boldsymbol{\square})$ of $\mathrm{Ca}^{2+}$. A standard curve of fluorescence intensity per mg of S100-488 was used to determine the experimental amount of labeled S100 per dot of target protein $(n=17)$.

interactions have hydrophobic residues in their C-terminal extension [150].

\section{Summary}

In summary, S100 family members have a distinct role in intracellular $\mathrm{Ca}^{2+}$ signaling. The complement of S100s and S100 target proteins expressed in an individual cell allows that cell to transduce a universal change in $\left[\mathrm{Ca}^{2+}\right]_{\mathrm{i}}$ into a unique biological response. Furthermore, their unique metal binding properties and diverse lists of target proteins provide mechanisms for conferring $\mathrm{Ca}^{2+} /$ metal sensitivity to cellular processes as well as integration and cross-talk among these processes. Thus, delineating S100-regulated processes in different cell types, ascertaining the relationship between intracellular and extracellular S100s, determining how S100regulated processes are altered by $\mathrm{Ca}^{2+}$ dysregulation in disease states, and identifying that the molecular events involved are critical for understanding the function of this versatile protein family. The combination of structural, biochemical, molecular, cell biological, and in vivo techniques, which has been successful to date, will ultimately identify "inhibitors" of $\mathrm{S} 100$ function that can be used to normalize $\mathrm{Ca}^{2+}$ signaling in diseased cells.

\section{Materials and Methods}

3.1. Bacterial Expression Vectors for Wild-Type S100 Family Members. The pVex expression vector for human S100P was a generous gift of Dr. George Makhatadze [151]. Bacterial expression vectors for S100A1 and S100B have been previously described [152]. Plasmids encoding rat S100A4 (GenBank accession number AA997272) and S100A5 (GenBank accession number 1772854) were obtained through the IMAGE consortium library (Research Genetics, Huntsville,
$\mathrm{AL})$. The coding sequences were amplified using gene specific primers containing synthetic Nde I and Hind III sites at the $5^{\prime}$ and $3^{\prime}$ ends of the coding sequence, respectively. The nucleotide sequences for the primers were 5' -TTCCATATGGCGAGACCCTTGGAGGAG-3' and 5' CCCAAGCTTCACTTCTTCCGGGGCTCC-3' (Lone Star Labs, Houston, TX) for S100A4, 5' -TTCCATATGGAGACTCCTCTTGAGAAG-3' (Invitrogen, Carlsbad, CA) and $5^{\prime}-$ CCCAAGCTTCACTTGTTGTCCTCTAAG-3' (Lone Star Labs) for S100A5. Gene amplification was performed using an initial heat step $\left(94^{\circ} \mathrm{C}, 5\right.$ minutes) followed by 30 cycles consisting of 1 minute at $94^{\circ} \mathrm{C}, 1$ minute at $60^{\circ} \mathrm{C}$, and 2 minutes at $68^{\circ} \mathrm{C}$, and a final extension step of 7 minutes at $68^{\circ} \mathrm{C}$. The resulting PCR products were subcloned into the TA cloning vector PCR2.1 (Invitrogen, Carlsbad, CA). The coding sequences were isolated from Nde I-Hind III digests of plasmid DNA and subcloned into pET21a ${ }^{+}$(Novagen, San Diego, CA). The entire protein coding sequence was verified by DNA sequence analysis.

3.2. Bacterial Expression Vectors for Mutant S100 Proteins. The bacterial expression vector for the S100A1 triple point mutant (F88/89A-W90A) has been described previously [152]. A two-step PCR protocol followed by directional subcloning was used to generate the expression vector for the S100B-A1-B chimeric protein in which the amino acid sequence for the linker region in S100B (HFLEEIKEQ) was replaced with the S100A1 linker region (SFLDVQKDA). A sense oligonucleotide containing the amino terminal S100B sequence with an engineered Nde I restriction site ( $5^{\prime}-$ CGCCATATGTCTGAACTCGAGAAAGCTG, Invitrogen) and a $3^{\prime}$ antisense oligonucleotide encoding the amino terminal half of the $\mathrm{S} 100 \mathrm{~A} 1$ linker region and an $\mathrm{Xba}$ I site (5'-CCTCTAGAAAGCTGCTAAGTTC, Invitrogen) were used to generate the $5^{\prime}$ half of the chimeric protein. The $3^{\prime}$ half of the chimeric protein was generated using the same template, a sense oligonucleotide encoding the carboxyl terminal half of the S100A1 linker region and an Xba I restriction enzyme site (5'-GCCATTTTCTAGACGTCCAGAAGGACGCGGAAGTTGTAGAC-3', Integrated DNA Technologies, Coralville, IA) and an antisense oligonucleotide encoding the amino terminus of S100B with an engineered Hind III site (5' -CCCAAGCTTATTCATGTTCG, Intergrated DNA Technologies). The PCR program consisted of 30 cycles ( 1 minute denaturing at $94^{\circ} \mathrm{C}, 1$ minute of annealing at $55^{\circ} \mathrm{C}$, and 3 minutes of extension at $72^{\circ} \mathrm{C}$ ). The resulting PCR products were ligated into the TA cloning vector PCR2.1. Purified insert DNA encoding the two halves of the chimeric protein was ligated together and subcloned into pET2 $1 \mathrm{a}^{+}$using the $5^{\prime}$ Nde I and $3^{\prime}$ Hind III restriction sites. Restriction enzyme digest and sequence analysis confirmed that the insert sequence encoded a protein with the appropriate amino acid sequence changes.

3.3. Expression/Purification of Recombinant S100 Proteins. Recombinant S100B, S100A1, and S100A1 triple point mutant were purified as previously described [152]. Minor modifications in this procedure were made to optimize 


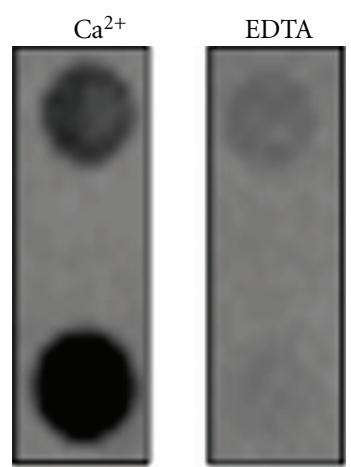

A1-488

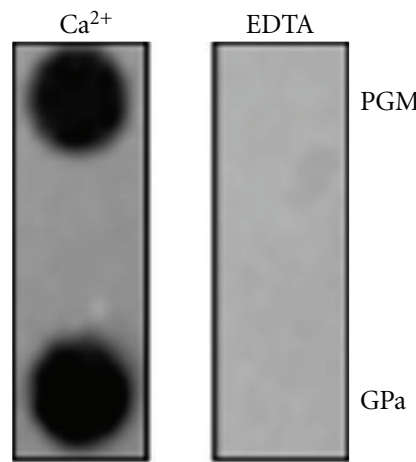

A1-488

(a)

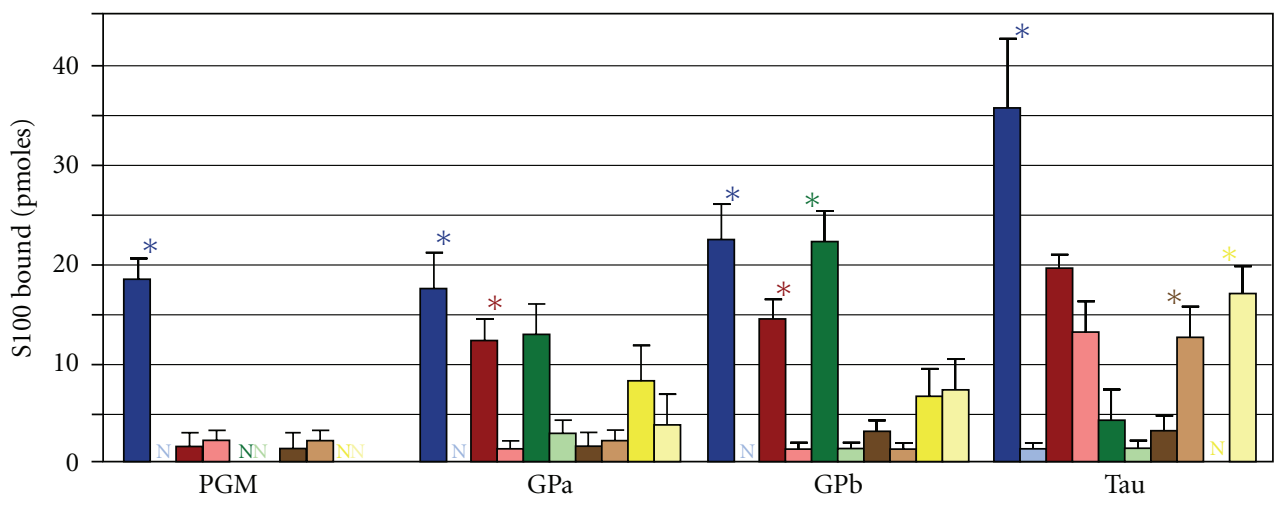

(b)

FIGURE 8: Target protein binding profiles for S100 family members. Membranes containing glycogen phosphorylase (a) (Gpa), glycogen phosphorylase (b) (Gpb), phosphoglucomutase (PGM), and tau (50 pmoles) were incubated in 100 nM Alexa Flour 488 labeled S100B (blue bars), S100A1 (red bars), S100P (green bars), S100A4 (brown bars), and S100A5 (yellow bars) in the presence (darker bars) or absence (lighter bars) of $\mathrm{Ca}^{2+}$. The histograms depict that the mean pmoles S100 bound \pm the SEM and N's denote no detectable binding. Asterisks denote $P \leq .05$ between the $\pm \mathrm{Ca}^{2+}$ conditions.

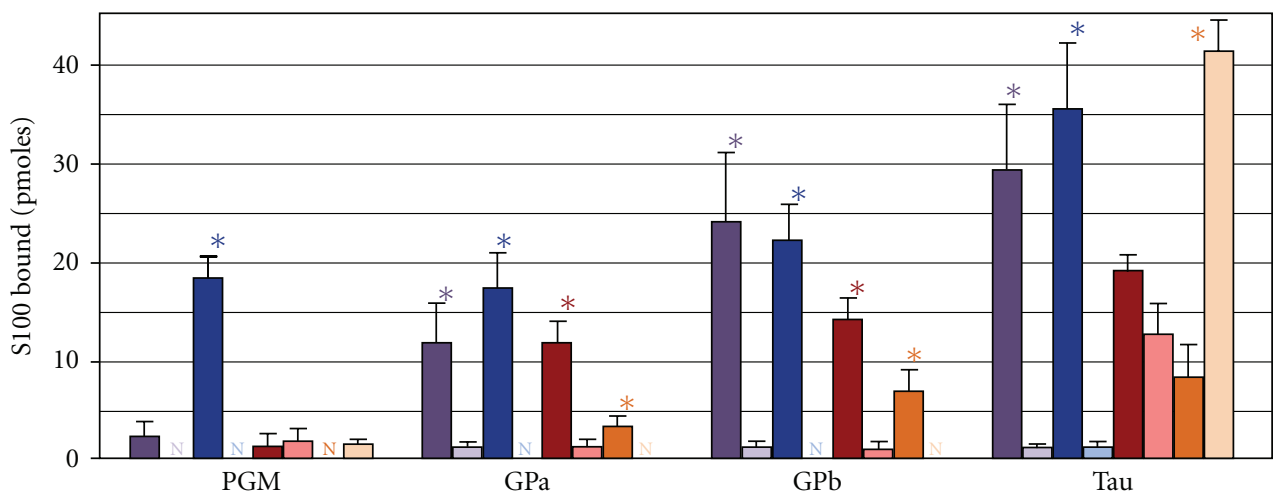

FIGURE 9: Interaction of wild-type and mutant S100s with target proteins. Membranes containing 50 pmoles glycogen phosphorylase a (Gpa), glycogen phosphorylase b (Gpb), phosphoglucomutase (PGM), and tau were incubated in 100 nM S100B-488 (blue bars), S100A1-488 (red bars), chimeric S100B-A1-B-488 (purple bars), or S100A1(F88/89A-W90A)-488 (orange bars) in the presence (darker bars) or absence (lighter bars) of $\mathrm{Ca}^{2+}$. The histograms depict that the mean pmoles S100 bound \pm the SEM and N's denote no detectable binding. The asterisks denote $P \leq .05$, and the N's denote no detectable binding between the $\pm \mathrm{Ca}^{2+}$ conditions.

purification for S100A4, S100A5, S100P, and the S100B-A1B chimera. Unboiled bacterial lysates for S100A4, S100A5, and S100P were fractionated by ammonium sulfate precipitation. Prior to phenyl-Sepharose chromatography, solid ammonium sulfate was added up to $30 \%(\mathrm{w} / \mathrm{v})$ to S100A4 [153] and up to $60 \%$ for S100P and S100A5. The unboiled S100B-A1-B lysate and the S100A4, S100A5, and S100P ammonium sulfate fractions were chromatographed on 
phenyl-Sepharose resin equilibrated with $50 \mathrm{mM}$ Tris- $\mathrm{Cl} \mathrm{pH}$ 7.4, $5 \mathrm{mM} \mathrm{CaCl}_{2}$, and $1 \mathrm{mM} \beta$-mercaptoethanol. The resin was washed with buffer containing high salt $(50 \mathrm{mM}$ Tris- $\mathrm{Cl}$ $\mathrm{pH} 7.4,5 \mathrm{mM} \mathrm{CaCl}_{2}, 1 \mathrm{mM} \beta$-mercaptoethanol, and $500 \mathrm{mM}$ $\mathrm{NaCl}$ ). Protein was eluted in $50 \mathrm{mM}$ Tris-Cl, $\mathrm{pH} 7.4,5 \mathrm{mM}$ EDTA, and $1 \mathrm{mM}$ DTT. Fractions containing S100 protein were identified by SDS-PAGE and pooled. The purity of the protein preparations was assessed by SDS-PAGE. Protein samples were considered to be $>95 \%$ pure when only a single band of $\sim 10,000 \mathrm{kDa}$ was visible on the Coomassie-blue stained gel.

3.4. Alexa Fluor Conjugation. All wild-type and mutant S100 proteins $(5.0 \mathrm{mg} / \mathrm{ml}$ in PBS) were labeled with the photostable fluorophore, Alexa Fluor 488 (Molecular Probes, Eugene, OR), according to the manufacturer's recommendations. Prior to labeling, the $\mathrm{pH}$ was adjusted to $\sim 8.3$ with $1 \mathrm{M}$ sodium bicarbonate and EDTA was added to a final concentration of $5.0 \mathrm{mM}$. Alexa Fluor 488 dye (1 mg) dissolved in DMSO was added to the protein sample. The reaction was incubated at room temperature for one hour in the dark with continuous stirring. Unconjugated dye was hydrolyzed by incubation of the solution overnight in the dark at $4^{\circ} \mathrm{C}$. After dilution with 1-2 volumes of water, the $\mathrm{pH}$ of the solution was adjusted to 7.4 by the addition of $2 \mathrm{M}$ Tris- $\mathrm{Cl} \mathrm{pH}$ 7.4. Free dye was separated from protein conjugates by $\mathrm{Ca}^{2+}$-dependent phenyl-Sepharose chromatography as described for protein purification. Next, we determined if this methodology could be used to quantify the binding of S100 proteins to their various target proteins. Alexa Fluor 488 labeled S100A1, S100B, S100A4, S100A5, and S100P exhibited physical characteristics that were indistinguishable from unlabeled proteins including $\mathrm{Ca}^{2+}$-dependent binding to phenyl-Sepharose (data not shown).

3.5. S100-Target Protein Binding Assay. Glycogen phosphorylase a, glycogen phosphorylase b, phosphoglucomutase (PGM), and phosphorylase kinase were purchased from Sigma Chemical Company (St. Louis, MO). Bovine brain tau and calmodulin-dependent kinase II (CaM kinase II) were generous gifts of Gloria Lee (University of Iowa) and Tom Soderling (Vollum Institute, Portland, OR), respectively. Varying concentrations of the target proteins were immobilized on Immobilon-P PVDF membrane (Millipore) using a 96-well dot-blot apparatus (BioRad, Hercules, CA) per supplier's instructions. After a 30-minute incubation, wells were washed twice with three volumes of $20 \mathrm{mM}$ Tris$\mathrm{Cl} \mathrm{pH} \mathrm{7.4.} \mathrm{The} \mathrm{membrane} \mathrm{was} \mathrm{removed} \mathrm{from} \mathrm{the} \mathrm{dot-}$ blot apparatus, cut into strips, and incubated overnight at room temperature in $1 \mu \mathrm{M}$ Alexa Flour 488-labeled protein in $50 \mathrm{mM}$ Tris-Cl, pH 7.4 with $200 \mathrm{mM} \mathrm{NaCl}$ (buffer A) containing either $5 \mathrm{mM}$ EDTA or $1 \mathrm{mM} \mathrm{CaCl} 2$. The strips were rinsed three times in buffer $A$ containing $5 \mathrm{mM}$ EDTA or $1 \mathrm{mM} \mathrm{CaCl}_{2}$ and fluorescence quantified on a Fuji FLA-5000 Image Analysis System (Stamford, CT). A standard curve of fluorescence intensity versus pmoles of PVDF-immobilized S100-488 (or Cam-488) was used to determine the pmoles of labeled protein bound to that concentration of target protein $(n \geq 2)$. Data points for each target protein concentration were averaged together to yield the mean pmoles of bound S100-488 \pm SEM which was calculated for each target protein. The student's $t$-test was used to determine the statistical significance $(P<.05)$ of any measured differences between the means.

\section{Acknowledgments}

The authors would like to acknowledge Drs. Patti Sadosky, Tamiko Porter, Paul Wilder, Kristen Varney, Nathan Wright, Thomas Charpentier, and John May for technical assistance. These studies were supported by start-up funds from Texas A \& M University (D. B. Zimmer) and grants from the $\mathrm{NIH}$ (GM58888, CA107331 to D. J. Weber).

\section{References}

[1] M. J. Berridge, M. D. Bootman, and H. L. Roderick, "Calcium signalling: dynamics, homeostasis and remodelling," Nature Reviews Molecular Cell Biology, vol. 4, no. 7, pp. 517-529, 2003.

[2] M. J. Berridge, "Inositol trisphosphate and calcium oscillations," Biochemical Society symposium, no. 74, pp. 1-7, 2007.

[3] B. W. Moore, "A soluble protein characteristic of the nervous system," Biochemical and Biophysical Research Communications, vol. 19, no. 6, pp. 739-744, 1965.

[4] T. Ravasi, K. Hsu, J. Goyette et al., "Probing the $\mathrm{S} 100$ protein family through genomic and functional analysis," Genomics, vol. 84, no. 1, pp. 10-22, 2004.

[5] R. Donato, "Intracellular and extracellular roles of S100 proteins," Microscopy Research and Technique, vol. 60, no. 6, pp. 540-551, 2003.

[6] R. Donato, "RAGE: a single receptor for several ligands and different cellular responses: the case of certain $\$ 100$ proteins," Current Molecular Medicine, vol. 7, no. 8, pp. 711-724, 2007.

[7] C. W. Heizmann, "The multifunctional S100 protein family," Methods in Molecular Biology, vol. 172, pp. 69-80, 2002.

[8] C. W. Heizmann, G. E. Ackermann, and A. Galichet, "Pathologies involving the S100 proteins and RAGE," SubCellular Biochemistry, vol. 45, pp. 93-138, 2007.

[9] C. W. Heizmann, G. Fritz, and B. W. Schäfer, "S100 proteins: structure, functions and pathology," Frontiers in Bioscience, vol. 7, pp. 1356-1368, 2002.

[10] D. J. Weber, R. R. Rustandi, F. Carrier, and D. B. Zimmer, Interaction of Dimeric S100B(bb) with the Tumor Suppressor Protein: A Model for Ca-Dependent S100-Target Protein Interactions, Kluwer Academic Publishers, Dordrecht, The Netherlands, 2000.

[11] D. B. Zimmer, J. Chaplin, A. Baldwin, and M. Rast, "S100mediated signal transduction in the nervous system and neurological diseases," Cellular and Molecular Biology, vol. 51, no. 2, pp. 201-214, 2005.

[12] D. B. Zimmer, P. Wright Sadosky, and D. J. Weber, "Molecular mechanisms of S100-target protein interactions," Microscopy Research and Technique, vol. 60, no. 6, pp. 552-559, 2003.

[13] R. Donato, "S100: a multigenic family of calcium-modulated proteins of the EF-hand type with intracellular and extracellular functional roles," International Journal of Biochemistry and Cell Biology, vol. 33, no. 7, pp. 637-668, 2001. 
[14] C. W. Heizmann, "Ca2 $2^{+}$-binding S100 proteins in the central nervous system," Neurochemical Research, vol. 24, no. 9, pp. 1097-1100, 1999.

[15] C. W. Heizmann and J. A. Cox, "New perspectives on s100 proteins: a multi-functional $\mathrm{Ca}^{2+}-, \mathrm{Zn}^{2+}$ - and $\mathrm{Cu}^{2+}$-binding protein family," BioMetals, vol. 11, no. 4, pp. 383-397, 1998.

[16] I. Marenholz, C. W. Heizmann, and G. Fritz, "S100 proteins in mouse and man: from evolution to function and pathology (including an update of the nomenclature)," Biochemical and Biophysical Research Communications, vol. 322, no. 4, pp. 1111-1122, 2004.

[17] A. C. Drohat, E. Nenortas, D. Beckett, and D. J. Weber, "Oligomerization state of S100b at nanomolar concentration determined by large-zone analytical gel filtration chromatography," Protein Science, vol. 6, no. 7, pp. 1577-1582, 1997.

[18] K. G. Inman, R. Yang, R. R. Rustandi, K. E. Miller, D. M. Baldisseri, and D. J. Weber, "Solution NMR structure of S100B bound to the high-affinity target peptide TRTK-12," Journal of Molecular Biology, vol. 324, no. 5, pp. 1003-1014, 2002.

[19] S. Bhattacharya, E. Large, C. W. Heizmann, B. Hemmings, and W. J. Chazin, "Structure of the $\mathrm{Ca}^{2+} / \mathrm{S} 100 \mathrm{~B} / \mathrm{NDR}$ kinase peptide complex: insights into S100 target specificity and activation of the kinase," Biochemistry, vol. 42, no. 49, pp. 14416-14426, 2003.

[20] T. H. Charpentier, P. T. Wilder, M. A. Liriano et al., "Divalent metal ion complexes of S100B in the absence and presence of pentamidine," Journal of Molecular Biology, vol. 382, no. 1, pp. $56-73,2008$.

[21] T. H. Charpentier, P. T. Wilder, M. A. Liriano et al., "Small molecules bound to unique sites in the target protein binding cleft of calcium-bound S100B as characterized by nuclear magnetic resonance and X-ray crystallography," Biochemistry, vol. 48, no. 26, pp. 6202-6212, 2009.

[22] A. C. Drohat, J. C. Amburgey, F. Abildgaard, M. R. Starich, D. Baldisseri, and D. J. Weber, "Solution structure of rat $\mathrm{Apo}-\mathrm{S} 100 \mathrm{~B}(\beta \beta)$ as determined by NMR spectroscopy," Biochemistry, vol. 35, no. 36, pp. 11577-11588, 1996.

[23] A. C. Drohat, D. M. Baldisseri, R. R. Rustandi, and D. J. Weber, "Solution structure of calcium-bound rat $\mathrm{S} 100 \mathrm{~B}(\beta \beta)$ as determined by nuclear magnetic resonance spectroscopy," Biochemistry, vol. 37, no. 9, pp. 2729-2740, 1998.

[24] A. C. Drohat, N. Tjandra, D. M. Baldisseri, and D. J. Weber, "The use of dipolar couplings for determining the solution structure of rat apo-S100B ( $\beta \beta)$," Protein Science, vol. 8, no. 4, pp. 800-809, 1999.

[25] P. M. Kilby, L. J. Van Eldik, and G. C. K. Roberts, "The solution structure of the bovine S100B protein dimer in the calcium-free state," Structure, vol. 4, no. 9, pp. 1041-1052, 1996.

[26] H. Matsumura, T. Shiba, T. Inoue, S. Harada, and Y. Kai, "A novel mode of target recognition suggested by the $2.0 \AA$ structure of holo S100B from bovine brain," Structure, vol. 6, no. 2, pp. 233-241, 1998.

[27] K. A. McClintock and G. S. Shaw, "A novel S100 target conformation is revealed by the solution structure of the $\mathrm{Ca}^{2+}$ S100B-TRTK-12 complex," Journal of Biological Chemistry, vol. 278, no. 8, pp. 6251-6257, 2003.

[28] T. Ostendorp, E. Leclerc, A. Galichet et al., "Structural and functional insights into RAGE activation by multimeric S100B," EMBO Journal, vol. 26, no. 16, pp. 3868-3878, 2007.

[29] R. R. Rustandi, D. M. Baldisseri, and D. J. Weber, "Structure of the negative regulatory domain of p53 bound to
S100B $(\beta \beta)$," Nature Structural Biology, vol. 7, no. 7, pp. 570$574,2000$.

[30] P. T. Wilder, K. M. Varney, M. B. Weiss, R. K. Gitti, and D. J. Weber, "Solution structure of Zinc- and calcium-bound rat $\mathrm{S} 100 \mathrm{~B}$ as determined by nuclear magnetic resonance spectroscopy," Biochemistry, vol. 44, no. 15, pp. 5690-5702, 2005.

[31] J. C. Amburgey, F. Abildgaard, M. R. Starich, S. Shah, D. C. Hilt, and D. J. Weber, "1H, 13C and 15N NMR assignments and solution secondary structure of rat Apo-S100 $\beta$," Journal of Biomolecular NMR, vol. 6, no. 2, pp. 171-179, 1995.

[32] D. E. Brodersen, M. Etzerodt, P. Madsen et al., "EF-hands at atomic resolution: the structure of human psoriasin (S100A7) solved by MAD phasing," Structure, vol. 6, no. 4, pp. 477-489, 1998.

[33] D. E. Brodersen, J. Nyborg, and M. Kjeldgaard, "Zincbinding site of an $\mathrm{S} 100$ protein revealed. Two crystal structures of $\mathrm{Ca}^{2+}$-bound human psoriasin (S100A7) in the $\mathrm{Zn}^{2+}$-loaded and $\mathrm{Zn}^{2+}$-free states," Biochemistry, vol. 38, no. 6, pp. 1695-1704, 1999.

[34] T. H. Charpentier, L. E. Thompson, M. A. Liriano, et al., "The effects of CapZ peptide (TRTK-12) binding to S100B-Ca ${ }^{2+}$ as examined by NMR and X-ray crystallography," Journal of Molecular Biology, vol. 396, pp. 1227-1243, 2010.

[35] T. H. Charpentier, P. T. Wilder, K. M. Varney, E. A. Toth, and D. J. Weber, "Crystal structure of pentamidine bound to $\mathrm{Ca}^{2+}$-S100B," AACR Meeting Abstracts, vol. 2006, 2006, 456b-.

[36] G. Fritz, P. R. E. Mittl, M. Vasak, M. G. Grütter, and C. W. Heizmann, "The crystal structure of metal-free human EF-hand protein S100A3 at 1.7- $\AA$ resolution," Journal of Biological Chemistry, vol. 277, no. 36, pp. 33092-33098, 2002.

[37] P. Groves, B. E. Finn, J. Kuźnicki, and S. Forsén, "A model for target protein binding to calcium-activated S100 dimers," FEBS Letters, vol. 421, no. 3, pp. 175-179, 1998.

[38] H. Itou, M. Yao, I. Fujita et al., "The crystal structure of human MRP14 (S100A9), a Ca ${ }^{2+}$-dependent regulator protein in inflammatory process," Journal of Molecular Biology, vol. 316, no. 2, pp. 265-276, 2002.

[39] P. M. Kilby, L. J. Van Eldik, and G. C. K. Robert, "Nuclear magnetic resonance assignments and secondary structure of bovine $S 100 \beta$ protein,” FEBS Letters, vol. 363, no. 1-2, pp. 9096, 1995.

[40] I. P. Korndörfer, F. Brueckner, and A. Skerra, "The crystal structure of the human (S100A8/S100A9)2 heterotetramer, calprotectin, illustrates how conformational changes of interacting $\alpha$-helices can determine specific association of two EFhand proteins," Journal of Molecular Biology, vol. 370, no. 5, pp. 887-898, 2007.

[41] T. Kouno, M. Mizuguchi, M. Sakaguchi et al., "The structure of S100A11 fragment explains a local structural change induced by phosphorylation," Journal of Peptide Science, vol. 14, no. 10, pp. 1129-1138, 2008.

[42] V. N. Malashkevich, K. M. Varney, S. C. Garrett et al., "Structure of $\mathrm{Ca}^{2+}$-bound S100A4 and its interaction with peptides derived from nonmuscle myosin-IIA," Biochemistry, vol. 47, no. 18, pp. 5111-5126, 2008.

[43] L. Mäler, B. C. M. Potts, and W. J. Chazin, "High resolution solution structure of apo calcyclin and structural variations in the S100 family of calcium-binding proteins," Journal of Biomolecular NMR, vol. 13, no. 3, pp. 233-247, 1999.

[44] L. Mäler, M. Sastry, and W. J. Chazin, "A structural basis for S100 protein specificity derived from comparative analysis 
of apo and $\mathrm{Ca}^{2+}$-calcyclin," Journal of Molecular Biology, vol. 317, no. 2, pp. 279-290, 2002.

[45] S. Malik, M. Revington, S. P. Smith, and G. S. Shaw, "Analysis of the structure of human apo-S100B at low temperature indicates a unimodal conformational distribution is adopted by calcium-free S100 proteins," Proteins, vol. 73, no. 1, pp. 28-42, 2008.

[46] P. R. E. Mittl, G. Fritz, D. F. Sargent, T. J. Richmond, C. W. Heizmann, and M. G. Grütter, "Metal-free MIRAS phasing: structure of apo-S100A3," Acta Crystallographica Section D, vol. 58, no. 8, pp. 1255-1261, 2002.

[47] O. V. Moroz, A. A. Antson, E. J. Dodson et al., "The structure of S100A12 in a hexameric form and its proposed role in receptor signalling," Acta Crystallographica Section D, vol. 58, no. 3, pp. 407-413, 2002.

[48] O. V. Moroz, A. A. Antson, S. J. Grist et al., "Structure of the human S100A12-copper complex: implications for hostparasite defence," Acta Crystallographica D, vol. 59, no. 5, pp. 859-867, 2003.

[49] O. V. Moroz, A. A. Antson, G. N. Murshudov et al., "The three-dimensional structure of human S100A12," Acta Crystallographica Section D, vol. 57, no. 1, pp. 20-29, 2001.

[50] O. V. Moroz, G. G. Dodson, K. S. Wilson, E. Lukanidin, and I. B. Bronstein, "Multiple structural states of S100A12: a key to its functional diversity," Microscopy Research and Technique, vol. 60, no. 6, pp. 581-592, 2003.

[51] L. R. Otterbein, J. Kordowska, C. Witte-Hoffmann, C.-L. A. Wang, and R. Dominguez, "Crystal structures of S100A6 in the $\mathrm{Ca}^{2+}$-free and $\mathrm{Ca}^{2+}$-bound states: the calcium sensor mechanism of $\mathrm{S} 100$ proteins revealed at atomic resolution," Structure, vol. 10, no. 4, pp. 557-567, 2002.

[52] B. C. M. Potts, G. Carlström, K. Okazaki, H. Hidaka, and W. J. Chazin, "1H NMR assignments of apo calcyclin and comparative structural analysis with calbindin $\mathrm{d}(9 \mathrm{k})$ and $\mathrm{s}$ 100ß," Protein Science, vol. 5, no. 11, pp. 2162-2174, 1996.

[53] B. C. M. Potts, J. Smith, M. Akke et al., "The structure of calcyclin reveals a novel homodimeric fold for S100 $\mathrm{Ca}^{2+}$ binding proteins," Nature Structural Biology, vol. 2, no. 9, pp. 790-796, 1995.

[54] S. Réty, D. Osterloh, J.-P. Arié et al., "Structural basis of the $\mathrm{Ca}^{2+}$-dependent association between S100C (S100A11) and its target, the N-terminal part of annexin I," Structure, vol. 8, no. 2, pp. 175-184, 2000.

[55] S. Réty, J. Sopkova, M. Renouard et al., "The crystal structure of a complex of p11 with the annexin II N-terminal peptide," Nature Structural Biology, vol. 6, no. 1, pp. 89-95, 1999.

[56] R. R. Rustandi, D. M. Baldisseri, K. G. Inman et al., "Threedimensional solution structure of the calcium-signaling protein apo-S100A1 as determined by NMR," Biochemistry, vol. 41, no. 3, pp. 788-796, 2002.

[57] S. P. Smith and G. S. Shaw, "A change-in-hand mechanism for S100 signalling," Biochemistry and Cell Biology, vol. 76, no. 2-3, pp. 324-333, 1998.

[58] P. T. Wilder, D. M. Baldisseri, R. Udan, K. M. Vallely, and D. J. Weber, "Location of the $\mathrm{Zn}^{2+}$-binding site on S100B as determined by NMR spectroscopy and site-directed mutagenesis," Biochemistry, vol. 42, no. 46, pp. 13410-13421, 2003.

[59] N. T. Wright, B. R. Cannon, P. T. Wilder et al., "Solution structure of S100A1 bound to the CapZ peptide (TRTK12)," Journal of Molecular Biology, vol. 386, no. 5, pp. 1265-1277, 2009.

[60] N. T. Wright, B. L. Prosser, K. M. Varney, D. B. Zimmer, M. F. Schneider, and D. J. Weber, "S100A1 and calmodulin compete for the same binding site on ryanodine receptor," Journal of Biological Chemistry, vol. 283, no. 39, pp. 2667626683, 2008.

[61] N. T. Wright, K. M. Varney, K. C. Ellis et al., "The threedimensional solution structure of $\mathrm{Ca}^{2+}$-bound S100A1 as determined by NMR spectroscopy," Journal of Molecular Biology, vol. 353, no. 2, pp. 410-426, 2005.

[62] H. Zhang, G. Wang, Y. Ding et al., "The crystal structure at $2 \AA$ Åsolution of the $\mathrm{Ca}^{2+}$-binding protein S100P," Journal of Molecular Biology, vol. 325, no. 4, pp. 785-794, 2003.

[63] I. Zhukov, A. Ejchart, and A. Bierzyński, "Structural and motional changes induced in apo-S100A1 protein by the disulfide formation between its Cys 85 residue and $\beta$ mercaptoethanol," Biochemistry, vol. 47, no. 2, pp. 640-650, 2008.

[64] P. T. Wilder, T. H. Charpentier, and M. Liriano, "In vitro screening and structural characterization of inhibitors of the S100B-p53 interaction," International Journal of High Throughput Screening, vol. 1, pp. 109-126, 2010.

[65] D. Kligman and D. C. Hilt, "The S100 protein family," Trends in Biochemical Sciences, vol. 13, no. 11, pp. 437-443, 1988.

[66] N. C. J. Strynadka and M. N. G. James, "Crystal structures of the helix-loop-helix calcium-binding proteins," Annual Review of Biochemistry, vol. 58, pp. 951-998, 1989.

[67] B. L. Prosser, N. T. Wright, E. O. Hernãndez-Ochoa et al., "S100A1 binds to the calmodulin-binding site of ryanodine receptor and modulates skeletal muscle excitationcontraction coupling," Journal of Biological Chemistry, vol. 283, no. 8, pp. 5046-5057, 2008.

[68] R. Donato, "Functional roles of S100 proteins, calciumbinding proteins of the EF-hand type," Biochimica et Biophysica Acta, vol. 1450, no. 3, pp. 191-231, 1999.

[69] P. T. Wilder, J. Lin, C. L. Bair et al., "Recognition of the tumor suppressor protein p53 and other protein targets by the calcium-binding protein S100B," Biochimica et Biophysica Acta, vol. 1763, no. 11, pp. 1284-1297, 2006.

[70] R. Donato, G. Sorci, F. Riuzzi et al., "S100B's double life: intracellular regulator and extracellular signal," Biochimica et Biophysica Acta, vol. 1793, no. 6, pp. 1008-1022, 2009.

[71] D. B. Zimmer and L. J. Van Eldik, "Identification of a molecular target for the calcium-modulated protein S100. Fructose-1,6-bisphosphate aldolase," Journal of Biological Chemistry, vol. 261, no. 24, pp. 11424-11428, 1986.

[72] A. Landar, G. Caddell, J. Chessher, and D. B. Zimmer, "Identification of an S100A1/S100B target protein: phosphoglucomutase," Cell Calcium, vol. 20, no. 3, pp. 279-285, 1996.

[73] D. B. Zimmer and J. G. Dubuisson, "Identification of an S100 target protein: glycogen phosphorylase," Cell Calcium, vol. 14, no. 4, pp. 323-332, 1993.

[74] H. Endo, K. Takenaga, T. Kanno, H. Satoh, and S. Mori, "Methionine aminopeptidase 2 is a new target for the metastasis-associated protein, S100A4," Journal of Biological Chemistry, vol. 277, no. 29, pp. 26396-26402, 2002.

[75] A. Filipek, B. Jastrzebska, M. Nowotny, and J. Kuznicki, "CacyBP/SIP, a calcyclin and Siah-1-interacting protein, binds EF-hand proteins of the S100 family," Journal of Biological Chemistry, vol. 277, no. 32, pp. 28848-28852, 2002.

[76] J. Baudier, C. Delphin, D. Grunwald, S. Khochbin, and J. J. Lawrence, "Characterization of the tumor suppressor protein p53 as a protein kinase C substrate and a S100b-binding protein," Proceedings of the National Academy of Sciences of the United States of America, vol. 89, no. 23, pp. 11627-11631, 1992. 
[77] R. R. Rustandi, D. M. Baldisseri, A. C. Drohat, and D. J. Weber, "Structural changes in the C-terminus of $\mathrm{Ca}^{2+}$-bound rat $\operatorname{S} 100 \mathrm{~B}(\beta \beta)$ upon binding to a peptide derived from the C-terminal regulatory domain of p53," Protein Science, vol. 8, no. 9, pp. 1743-1751, 1999.

[78] R. R. Rustandi, A. C. Drohat, D. M. Baldisseri, P. T. Wilder, and D. J. Weber, "The $\mathrm{Ca}^{2+}$-dependent interaction of $\operatorname{S100B}(\beta \beta)$ with a peptide derived from p53," Biochemistry, vol. 37, no. 7, pp. 1951-1960, 1998.

[79] J. Van Dieck, T. Brandt, D. P. Teufel, D. B. Veprintsev, A. C. Joerger, and A. R. Fersht, "Molecular basis of S100 proteins interacting with the p53 homologs p63 and p73," Oncogene, vol. 29, no. 14, pp. 2024-2035, 2010.

[80] J. van Dieck, M. R. Fernandez-Fernandez, D. B. Veprintsev, and A. R. Fersht, "Modulation of the oligomerization state of p53 by differential binding of proteins of the S100 family to p53 monomers and tetramers," Journal of Biological Chemistry, vol. 284, no. 20, pp. 13804-13811, 2009.

[81] J. Lin, M. Blake, C. Tang et al., "Inhibition of p53 transcriptional activity by the S100B calcium-binding protein," Journal of Biological Chemistry, vol. 276, no. 37, pp. 3503735041, 2001.

[82] J. Lin, Q. Yang, Z. Yan et al., "Inhibiting S100B restores p53 levels in primary malignant melanoma cancer cells," Journal of Biological Chemistry, vol. 279, no. 32, pp. 34071-34077, 2004.

[83] C. Scotto, J. C. Deloulme, D. Rousseau, E. Chambaz, and J. Baudier, "Calcium and S100B regulation of p53-dependent cell growth arrest and apoptosis," Molecular and Cellular Biology, vol. 18, no. 7, pp. 4272-4281, 1998.

[84] C. Scotto, C. Delphin, J. C. Deloulme, and J. Baudier, "Concerted regulation of wild-type p53 nuclear accumulation and activation by $\mathrm{S} 100 \mathrm{~B}$ and calcium-dependent protein kinase C," Molecular and Cellular Biology, vol. 19, no. 10, pp. 71687180, 1999.

[85] K. R. Barber, K. A. McClintock, G. A. Jamieson Jr., R. V. W. Dimlich, and G. S. Shaw, "Specificity and $\mathrm{Zn}^{2+}$ enhancement of the S100B binding epitope TRTK-12," Journal of Biological Chemistry, vol. 274, no. 3, pp. 1502-1508, 1999.

[86] J. Baudier, K. Haglid, J. Haiech, and D. Gerard, "Zinc ion binding to human brain calcium binding proteins, calmodulin and S100b protein," Biochemical and Biophysical Research Communications, vol. 114, no. 3, pp. 1138-1146, 1983.

[87] D. Chaudhuri, W. D. Horrocks Jr., J. C. Amburgey, and D. J. Weber, "Characterization of lanthanide ion binding to the EF-hand protein S100 $\beta$ by luminescence spectroscopy," Biochemistry, vol. 36, no. 32, pp. 9674-9680, 1997.

[88] G. E. Davey, P. Murmann, and C. W. Heizmann, "Intracellular $\mathrm{Ca}^{2+}$ and $\mathrm{Zn}^{2+}$ levels regulate the alternative cell densitydependent secretion of S100B in human glioblastoma cells," Journal of Biological Chemistry, vol. 276, no. 33, pp. 3081930826, 2001.

[89] C. Franz, I. Durussel, J. A. Cox, B. W. Schäfer, and C. W. Heizmann, "Binding of $\mathrm{Ca}^{2+}$ and $\mathrm{Zn}^{2+}$ to human nuclear S100A2 and mutant proteins," Journal of Biological Chemistry, vol. 273, no. 30, pp. 18826-18834, 1998.

[90] G. Fritz, C. W. Heizmann, and P. M. H. Kroneck, "Probing the structure of the human $\mathrm{Ca}^{2+}$ - and $\mathrm{Zn}^{2+}$-binding protein S100A3: spectroscopic investigations of its transition metal ion complexes, and three-dimensional structural model," Biochimica et Biophysica Acta, vol. 1448, no. 2, pp. 264-276, 1998.
[91] R. Gläser, J. Harder, H. Lange, J. Bartels, E. Christophers, and J.-M. Schröder, "Antimicrobial psoriasin (S100A7) protects human skin from Escherichia coli infection," Nature Immunology, vol. 6, no. 1, pp. 57-64, 2005.

[92] A. V. Gribenko and G. I. Makhatadze, "Oligomerization and divalent ion binding properties of the S100P protein: a $\mathrm{Ca}^{2+} / \mathrm{Mg}^{2+}$-switch model," Journal of Molecular Biology, vol. 283, no. 3, pp. 679-694, 1998.

[93] J. Heierhorst, R. J. Mann, and B. E. Kemp, "Interaction of the recombinant $S 100 \mathrm{~A} 1$ protein with twitchin kinase, and comparison with other $\mathrm{Ca}^{2+}$-binding proteins," European Journal of Biochemistry, vol. 249, no. 1, pp. 127-133, 1997.

[94] D. Hoyaux, J. Alao, J. Fuchs et al., "S100A6, a calciumand zinc-binding protein, is overexpressed in SOD1 mutant mice, a model for amyotrophic lateral sclerosis," Biochimica et Biophysica Acta, vol. 1498, no. 2-3, pp. 264-272, 2000.

[95] C. Kerkhoff, T. Vogl, W. Nacken, C. Sopalla, and C. Sorg, "Zinc binding reverses the calcium-induced arachidonic acid-binding capacity of the S100A8/A9 protein complex," FEBS Letters, vol. 460, no. 1, pp. 134-138, 1999.

[96] J. Kordowska, W. F. Stafford, and C.-L. A. Wang, " $\mathrm{Ca}^{2+}$ and $\mathrm{Zn}^{2+}$ bind to different sites and induce different conformational changes in human calcyclin," European Journal of Biochemistry, vol. 253, no. 1, pp. 57-66, 1998.

[97] G. O. Mbele, J. C. Deloulme, B. J. Gentil et al., "The zincand calcium-binding S100B interacts and co-localizes with IQGAP1 during dynamic rearrangement of cell membranes," Journal of Biological Chemistry, vol. 277, no. 51, pp. 4999850007, 2002.

[98] Y. Ogoma, H. Kobayashi, T. Fujii et al., "Binding study of metal ions to S100 protein: $43 \mathrm{Ca}, 25 \mathrm{Mg}, 67 \mathrm{Zn}$ and $39 \mathrm{~K}$ n.m.r," International Journal of Biological Macromolecules, vol. 14, no. 5, pp. 279-286, 1992.

[99] Y. Ogoma, T. Shimizu, H. Kobayashi et al., "Effects of $\mathrm{Ca}^{2+}$ and $\mathrm{Zn}^{2+}$ on trifluoperazine-S100 proteins interactions: induced circular dichroism and fluorescence spectra," Biochimica et Biophysica Acta, vol. 997, no. 3, pp. 188-192, 1989.

[100] J. C. Deloulme, N. Assard, G. O. Mbele, C. Mangin, R. Kuwano, and J. Baudier, "S100A6 and S100A11 are specific targets of the calcium- and zinc-binding S100B protein in vivo," Journal of Biological Chemistry, vol. 275, no. 45, pp. 35302-35310, 2000.

[101] J. C. Deloulme, B. J. Gentil, and J. Baudier, "Monitoring of S100 homodimerization and heterodimeric interactions by the yeast two-hybrid system," Microscopy Research and Technique, vol. 60, no. 6, pp. 560-568, 2003.

[102] A. V. Gribenko, J. E. Hopper, and G. I. Makhatadze, "Molecular characterization and tissue distribution of a novel member of the S100 family of EF-hand proteins," Biochemistry, vol. 40, no. 51, pp. 15538-15548, 2001.

[103] G. Wang, P. S. Rudland, M. R. White, and R. Barraclough, "Interaction in vivo and in vitro of the metastasis-inducing S100 protein, S100A4 (p9Ka) with S100A1," Journal of Biological Chemistry, vol. 275, no. 15, pp. 11141-11146, 2000.

[104] Q. Yang, D. O’Hanlon, C. W. Heizmann, and A. Marks, "Demonstration of heterodimer formation between S100B and S100A6 in the yeast two-hybrid system and human melanoma," Experimental Cell Research, vol. 246, no. 2, pp. 501-509, 1999.

[105] G. Hagens, I. Masouyé, E. Augsburger, R. Hotz, J.-H. Saurat, and G. Siegenthaler, "Calcium-binding protein S100A7 and epidermal-type fatty acid-binding protein are associated in 
the cytosol of human keratinocytes," Biochemical Journal, vol. 339, no. 2, pp. 419-427, 1999.

[106] C. Kerkhoff, M. Klempt, V. Kaever, and C. Sorg, "The two calcium-binding proteins, S100A8 and S100A9, are involved in the metabolism of arachidonic acid in human neutrophils," Journal of Biological Chemistry, vol. 274, no. 46, pp. 32672-32679, 1999.

[107] J. Baudier and D. Gérard, "Ions binding to S100 proteins: structural changes induced by calcium and zinc on S100a and S100b proteins," Biochemistry, vol. 22, no. 14, pp. 3360-3369, 1983.

[108] J. Baudier and D. Gerard, "Ions binding to S100 proteins. II. Conformational studies and calcium-induced conformational changes in $\mathrm{S} 100 \alpha \alpha$ protein: the effect of acidic $\mathrm{pH}$ and calcium incubation on subunit exchange in S100a $(\alpha \beta)$ protein," Journal of Biological Chemistry, vol. 261, no. 18, pp. 8204-8212, 1986.

[109] J. Markowitz, R. R. Rustandi, K. M. Varney et al., "Calciumbinding properties of wild-type and EF-hand mutants of $\mathrm{S} 100 \mathrm{~B}$ in the presence and absence of a peptide derived from the C-terminal negative regulatory domain of p53," Biochemistry, vol. 44, no. 19, pp. 7305-7314, 2005.

[110] K. L. Yap, J. B. Ames, M. B. Swindells, and M. Ikura, "Diversity of conformational states and changes within the EF-hand protein superfamily," Proteins: Structure, Function and Genetics, vol. 37, no. 3, pp. 499-507, 1999.

[111] S. P. Smith and G. S. Shaw, "A novel calcium-sensitive switch revealed by the structure of human $\mathrm{S} 100 \mathrm{~B}$ in the calciumbound form," Structure, vol. 6, no. 2, pp. 211-222, 1998.

[112] L. Santamaria-Kisiel, A. C. Rintala-Dempsey, and G. S. Shaw, "Calcium-dependent and -independent interactions of the S100 protein family," Biochemical Journal, vol. 396, no. 2, pp. 201-214, 2006.

[113] R. R. Rustandi, A. C. Drohat, D. M. Baldisseri, P. T. Wilder, and D. J. Weber, "The $\mathrm{Ca}^{2+}$-dependent interaction of $\operatorname{S100B}(\beta \beta)$ with a peptide derived from p53," Biochemistry, vol. 37, no. 7, pp. 1951-1960, 1998.

[114] J. Baudier and R. D. Cole, "The $\mathrm{Ca}^{2+}$-binding sequence in bovine brain $S 100 \mathrm{~b}$ protein $\beta$-subunit. A spectroscopic study," Biochemical Journal, vol. 264, no. 1, pp. 79-85, 1989.

[115] J. Baudier, N. Glasser, and D. Gerard, "Ions binding to S100 proteins. I. Calcium- and zinc-binding properties of bovine brain $\mathrm{S} 100 \alpha \alpha$, S100a $(\alpha \beta)$, and S100b $(\beta \beta)$ protein: $\mathrm{Zn}^{2+}$ regulates $\mathrm{Ca}^{2+}$ binding on S100b protein," Journal of Biological Chemistry, vol. 261, no. 18, pp. 8192-8203, 1986.

[116] J. Baudier, G. Labourdette, and D. Gerard, "Rat brain S100b protein: purification, characterization, and ion binding properties. A comparison with bovine S100b protein," Journal of Neurochemistry, vol. 44, no. 1, pp. 76-84, 1985.

[117] I. Durussel, L. J. Van Eldik, and J. A. Cox, "Ion-binding properties of recombinant $S 100 \beta$ and two derivatives with either an inactivated $\mathrm{Ca}^{2+}$ site II or a normalized $\mathrm{Ca}^{2+}$ site I," Biochimica et Biophysica Acta, vol. 1343, no. 2, pp. 139-143, 1997.

[118] D. R. Marshak, D. M. Watterson, and L. J. Van Eldik, "Calcium-dependent interaction of S100b, troponin C, and calmodulin with an immobilized phenothiazine," Proceedings of the National Academy of Sciences of the United States of America, vol. 78, no. 11, pp. 6793-6797, 1981.

[119] Y. Mely and D. Gerard, "Structural and ion-binding properties of an S100b protein mixed disulfide: comparison with the reappraised native S100b protein properties," Archives of Biochemistry and Biophysics, vol. 279, no. 1, pp. 174-182, 1990.
[120] N. Pozdnyakov, R. Goraczniak, A. Margulis et al., "Structural and functional characterization of retinal calcium-dependent guanylate cyclase activator protein (CD-GCAP): identity with S100 $\beta$ protein," Biochemistry, vol. 36, no. 46, pp. 1415914166, 1997.

[121] U. G. Fohr, C. W. Heizmann, D. Engelkamp, B. W. Schafer, and J. A. Cox, "Purification and cation binding properties of the recombinant human S100 calcium-binding protein A3, an EF-hand motif protein with high affinity for zinc," Journal of Biological Chemistry, vol. 270, no. 36, pp. 21056-21061, 1995.

[122] E. A. Dukhanina, A. S. Dukhanin, M. Y. Lomonosov, E. M. Lukanidin, and G. P. Georgiev, "Spectral studies on the calcium-binding properties of Mts 1 protein and its interaction with target protein," FEBS Letters, vol. 410, no. 2-3, pp. 403-406, 1997.

[123] M. Pedrocchi, B. W. Schafer, I. Durussel, J. A. Cox, and C. W. Heizmann, "Purification and characterization of the recombinant human calcium-binding S100 proteins CAPL and CACY," Biochemistry, vol. 33, no. 21, pp. 6732-6738, 1994.

[124] B. W. Schäfer, J.-M. Fritschy, P. Murmann et al., "Brain S100A5 is a novel calcium-, zinc-, and copper ion-binding protein of the EF-hand superfamily," Journal of Biological Chemistry, vol. 275, no. 39, pp. 30623-30630, 2000.

[125] J. Kuźnicki and A. Filipek, "Purification and properties of a novel $\mathrm{Ca}^{2+}$-binding protein $(10.5 \mathrm{kDa})$ from Ehrlich-ascitestumour cells," Biochemical Journal, vol. 247, no. 3, pp. 663667, 1987.

[126] R. S. Mani and C. M. Kay, "Isolation and characterization of a novel molecular weight $11000 \mathrm{Ca}^{2+}$-binding protein from smooth muscle," Biochemistry, vol. 29, no. 6, pp. 1398-1404, 1990.

[127] H. Vorum, P. Madsen, H. H. Rasmussen et al., "Expression and divalent cation binding properties of the novel chemotactic inflammatory protein psoriasin," Electrophoresis, vol. 17, no. 11, pp. 1787-1796, 1996.

[128] B. G. Allen, "Characterization of the $\mathrm{Ca}^{2+}$-binding properties of calgizzarin (S100C) isolated from chicken gizzard smooth muscle," Biochemistry and Cell Biology, vol. 74, no. 5, pp. 687694, 1996.

[129] E. C. Dell'Angelica, C. H. Schleicher, and J. A. Santome, "Primary structure and binding properties of calgranulin C, a novel S100- like calcium-binding protein from pig granulocytes," Journal of Biological Chemistry, vol. 269, no. 46, pp. 28929-28936, 1994.

[130] K. Ridinger, B. W. Schäfer, I. Durussel, J. A. Cox, and C. W. Heizmann, "S100A13. Biochemical characterization and subcellular localization in different cell lines," Journal of Biological Chemistry, vol. 275, no. 12, pp. 8686-8694, 2000.

[131] I. Marenholz, R. C. Lovering, and C. W. Heizmann, "An update of the S100 nomenclature," Biochimica et Biophysica Acta, vol. 1763, no. 11, pp. 1282-1283, 2006.

[132] E. Sturchler, J. A. Cox, I. Durussel, M. Weibel, and C. W. Heizmann, "S100A16, a novel calcium-binding protein of the EF-hand superfamily," Journal of Biological Chemistry, vol. 281, no. 50, pp. 38905-38917, 2006.

[133] T. Becker, V. Gerke, E. Kube, and K. Weber, "S100P, a novel $\mathrm{Ca}^{2+}$-binding protein from human placenta. cDNA cloning, recombinant protein expression and $\mathrm{Ca}^{2+}$ binding properties," European Journal of Biochemistry, vol. 207, no. 2, pp. 541-547, 1992.

[134] D. C. Hilt and D. Kligman, "The S100 protein family: a biochemical and functional overview," in Novel Calcium 
Binding Proteins, C. Heizmann, Ed., pp. 65-103, Springer, Berlin, Germany, 1991.

[135] A. S. Mildvan and L. A. Loeb, "The role of metal ions in the mechanisms of DNA and RNA polymerases," CRC Critical Reviews in Biochemistry, vol. 6, no. 3, pp. 219-244, 1979.

[136] K. G. Inman, D. M. Baldisseri, K. E. Miller, and D. J. Weber, "Backbone dynamics of the calcium-signaling protein apoS100B as determined by 15 N NMR relaxation," Biochemistry, vol. 40, no. 12, pp. 3439-3448, 2001.

[137] N. T. Wright, K. G. Inman, J. A. Levine, B. R. Cannon, K. M. Varney, and D. J. Weber, "Refinement of the solution structure and dynamic properties of $\mathrm{Ca}^{2+}$-bound rat S100B," Journal of Biomolecular NMR, vol. 42, no. 4, pp. 279-286, 2008.

[138] C. Wang, N. Karpowich, J. F. Hunt, M. Rance, and A. G. Palmer, "Dynamics of ATP-binding cassette contribute to allosteric control, nucleotide binding and energy transduction in ABC transporters," Journal of Molecular Biology, vol. 342, no. 2, pp. 525-537, 2004.

[139] T. H. Charpentier, L. E. Thompson, M. Liriano, et al., “The effects of the CapZ peptide (TRTK-12) binding to S100B$\mathrm{Ca}^{2+}$ as examined by NMR and X-ray crystallography," Journal of Molecular Biology, vol. 396, no. 5, pp. 1227-1243, 2010.

[140] P. Cohen, C. Picton, and C. B. Klee, "Activation of phosphorylase kinase from rabbit skeletal muscle by calmodulin and troponin," FEBS Letters, vol. 104, no. 1, pp. 25-30, 1979.

[141] T. Meyer, P. I. Hanson, L. Stryer, and H. Schulman, "Calmodulin trapping by calcium-calmodulin-dependent protein kinase," Science, vol. 256, no. 5060, pp. 1199-1202, 1992.

[142] A. Landar, G. Caddell, J. Chessher, and D. B. Zimmer, "Identification of an S100A1/S100B target protein: phosphoglucomutase," Cell Calcium, vol. 20, no. 3, pp. 279-285, 1996.

[143] K. A. McClintock, L. J. Van Eldik, and G. S. Shaw, "The Cterminus and linker region of S100B exert dual control on protein-protein interactions with TRTK-12," Biochemistry, vol. 41, no. 17, pp. 5421-5428, 2002.

[144] M. Garbuglia, M. Verzini, R. R. Rustandi et al., "Role of the C-terminal extension in the interaction of S100A1 with GFAP, tubulin, the S100A1- and S100B-inhibitory peptide, TRTK-12, and a peptide derived from p53, and the S100A1 inhibitory effect on GFAP polymerization," Biochemical and Biophysical Research Communications, vol. 254, no. 1, pp. 3641, 1999.

[145] D. Osterloh, V. V. Ivanenkov, and V. Gerke, "Hydrophobic residues in the C-terminal region of S100A1 are essential for target protein binding but not for dimerization," Cell Calcium, vol. 24, no. 2, pp. 137-151, 1998.

[146] E. Kube, T. Becker, K. Weber, and V. Gerke, "Protein-protein interaction studied by site-directed mutagenesis," Journal of Biological Chemistry, vol. 267, no. 20, pp. 14175-14182, 1992.

[147] P. T. Wilder, R. R. Rustandi, A. C. Drohat, and D. J. Weber, "S100b $(\beta \beta)$ inhibits the protein kinase C-dependent phosphorylation of a peptide derived from $\mathrm{p} 53$ in a $\mathrm{Ca}^{2+}$ dependent manner," Protein Science, vol. 7, no. 3, pp. 794798, 1998.

[148] S. Zhang, G. Wang, D. G. Fernig et al., "Interaction of metastasis-inducing S100A4 protein in vivo by fluorescence lifetime imaging microscopy," European Biophysics Journal, vol. 34, no. 1, pp. 19-27, 2005.

[149] S. Zhang, G. Wang, D. Liu et al., "The C-terminal region of S100A4 is important for its metastasis-inducing properties," Oncogene, vol. 24, no. 27, pp. 4401-4411, 2005.
[150] J. Choi, J.-S. Chang, M.-S. Song et al., "Association of hepatitis B virus polymerase with promyelocytic leukemia nuclear bodies mediated by the S100 family protein p11," Biochemical and Biophysical Research Communications, vol. 305, no. 4, pp. 1049-1056, 2003.

[151] A. Gribenko, M. M. Lopez, J. M. Richardson III, and G. I. Makhatadze, "Cloning, overexpression, purification, and spectroscopic characterization of human S100P," Protein Science, vol. 7, no. 1, pp. 211-215, 1998.

[152] A. Landar, R. R. Rustandi, D. J. Weber, and D. B. Zimmer, "S100A1 utilizes different mechanisms for interacting with calcium-dependent and calcium-independent target proteins," Biochemistry, vol. 37, no. 50, pp. 17429-17438, 1998.

[153] K. M. Vallely, R. R. Rustandi, K. C. Ellis, O. Varlamova, A. R. Bresnick, and D. J. Weber, "Solution structure of human Mts1 (S100A4) as determined by NMR spectroscopy," Biochemistry, vol. 41, no. 42, pp. 12670-12680, 2002. 


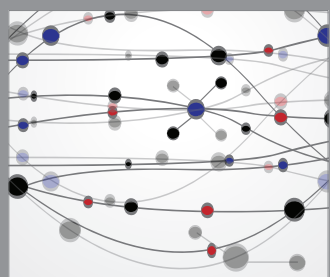

The Scientific World Journal
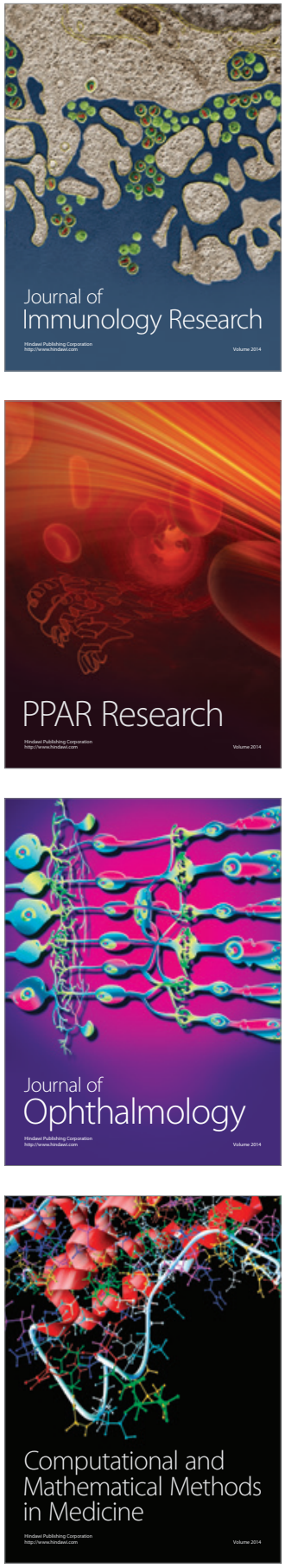

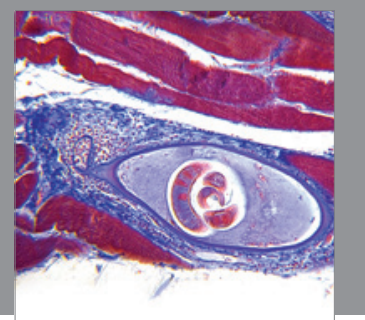

Gastroenterology

Research and Practice
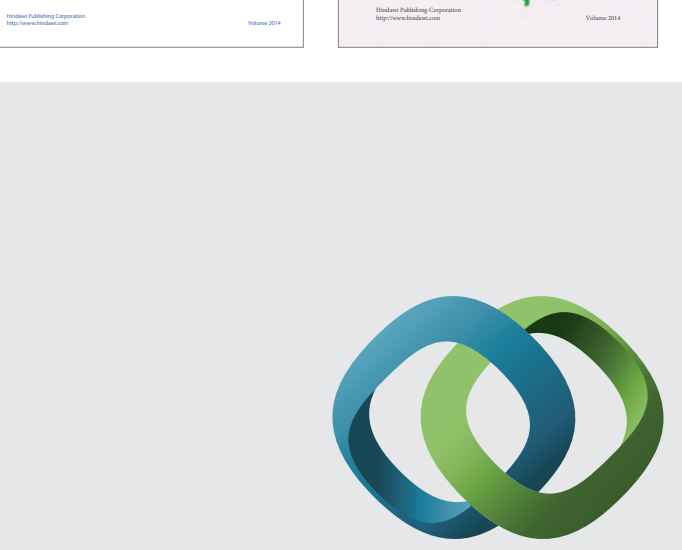

\section{Hindawi}

Submit your manuscripts at

http://www.hindawi.com
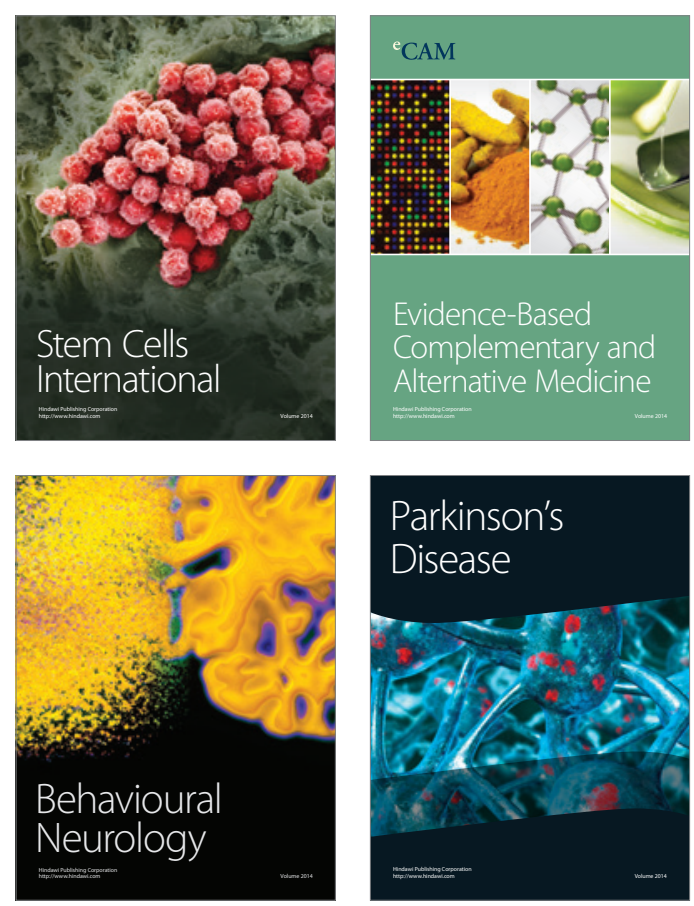

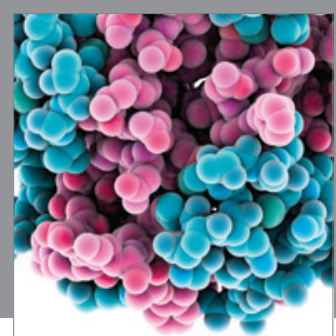

Journal of
Diabetes Research

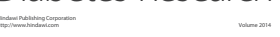

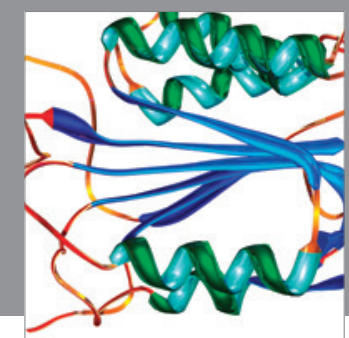

Disease Markers
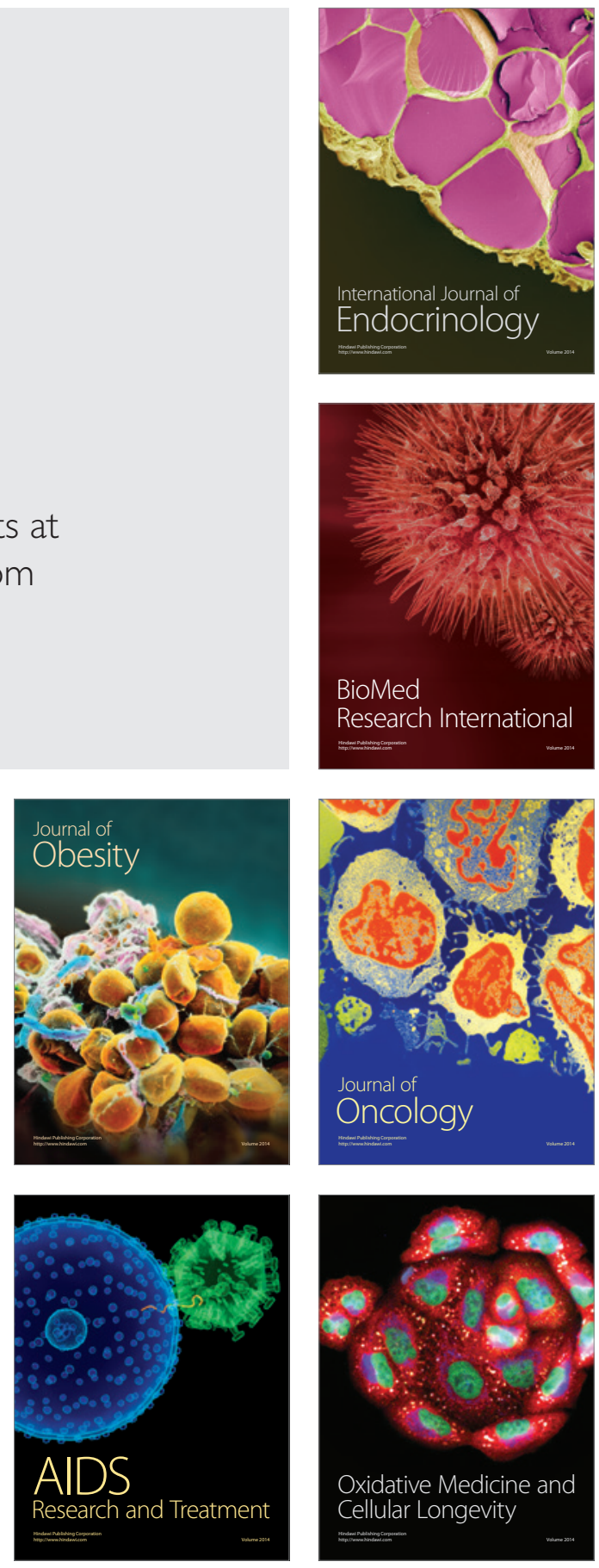